Keurhorst M, van de Glind I, do Amaral-Sabadini MB, Anderson P, Kaner E, Newbury-Birch D, Braspenning J, Wensing M, Heinen M, Laurant

M. Implementation strategies to enhance management of heavy alcohol consumption in primary health care: a meta-analysis. Addiction2015, 110(12), 1877-1900.

\title{
Copyright:
}

This is the peer reviewed version of the following article: Keurhorst $M$, van de Glind I, do Amaral-Sabadini $M B$, Anderson $P$, Kaner E, Newbury-Birch D, Braspenning J, Wensing M, Heinen M, Laurant M. Implementation strategies to enhance management of heavy alcohol consumption in primary health care: a meta-analysis. Addiction2015, 110(12), 1877-1900, which has been published in final form at http://dx.doi.org/10.1111/add.13088. This article may be used for non-commercial purposes in accordance with Wiley Terms and Conditions for Self-Archiving.

DOI link to article:

http://dx.doi.org/10.1111/add.13088

Date deposited:

07/03/2016

Embargo release date:

18 September 2016 
Implementation strategies to enhance management of heavy alcohol consumption in primary health care: A meta-analysis

Myrna Keurhorst $^{1,2^{*}}$, Irene van de Glind ${ }^{1}$, Michaela Bitarello do Amaral-Sabadini ${ }^{3}$, Peter Anderson ${ }^{4,5}$, Eileen Kaner ${ }^{4}$, Dorothy Newbury-Birch ${ }^{6}$, Jozé Braspenning ${ }^{1}$, Michel Wensing ${ }^{1}$, Maud Heinen ${ }^{1} \&$ Miranda Laurant ${ }^{1,7}$

${ }^{1}$ Radboud university medical center, Radboud Institute for Health Sciences, IQ healthcare, Nijmegen, the Netherlands

${ }^{2}$ Saxion University of Applied Sciences, Centre for Nursing Research, Deventer/Enschede, The Netherlands

${ }^{3}$ Independent consultant in public health, Brazil

${ }^{4}$ Newcastle University, Institute of Health and Society, Newcastle, United Kingdom

${ }^{5}$ Maastricht University, School Caphri, Department of Family Medicine, Maastricht, Netherlands

${ }^{6}$ Teesside University, Health and Social Care Institute, Middlesbrough, United Kingdom

${ }^{7}$ HAN University of Applied Sciences, Faculty of Health and Social Studies, Nijmegen, The Netherlands

*Corresponding author: Myrna Keurhorst, MSc; Radboud university medical center, Radboud Institute for Health Sciences, IQ healthcare, Post box 9101, 6500 HB Nijmegen, the Netherlands. T +31 24 3619326; F +31 243540166

E-mail: myrna.keurhorst@radboudumc.nl

WORD COUNT: 3450

NUMBER OF REFERENCES: 74

NUMBER OF TABLES: 6

NUMBER OF FIGURES: 4

ABSTRACT WORD LENGTH: 253

KEY WORDS: prevention of heavy alcohol consumption; screening; brief intervention; primary health care; implementation; systematic review; meta-analysis 


\section{Declarations of interest}

Myrna Keurhorst declares that she has no competing interests

Irene van de Glind declares that she has no competing interests

Michaela Bitarello do Amaral-Sabadini declares that she has no competing interests

Peter Anderson declares that he has no competing interests

Eileen Kaner declares that she has no competing interests

Dorothy Newbury-Birch declares that she has no competing interests

Jozé Braspenning declares that she has no competing interests

Michel Wensing declares that he has no competing interests

Maud Heinen declares that she has no competing interests

Miranda Laurant declares that she has no competing interests

\section{Funding source}

The European Community's Seventh Framework Programme (FP7/2007-2013), provided funding for the study under Grant Agreement $n^{\circ} 259268$ - Optimizing delivery of health care interventions (ODHIN). Radboud university medical center received co-funding from The Netherlands Organisation for Health Research and Development (ZonMW, Prevention Programme), under Grant Agreement no 200310017 - ODHIN - Optimizing delivery of health care interventions in the Netherlands, according Art.II.17 of the FP7 EC Grant Agreement. 


\begin{abstract}
Aims Screening and brief interventions (SBI) delivered in primary health care (PHC) are costeffective in decreasing alcohol consumption; however, they are underused. This study aims to identify implementation strategies that focus on SBI uptake and measure impact on: 1) heavy drinking; and 2) delivery of SBI in PHC.

Methods Meta-analysis was conducted of controlled trials of SBI implementation strategies in PHC to reduce heavy drinking. Key outcomes included alcohol consumption, screening, brief interventions and costs in PHC. Predictor measures concerned single versus multiple strategies, type of strategy, duration and physician-only input versus that including mid-level professionals. Standardised mean differences (SMD) were calculated to indicate the impact of implementation strategies on key outcomes. Effect sizes were aggregated using meta-regression models.
\end{abstract}

Results The 29 included studies were of moderate methodological quality. Strategies had no overall impact on patients' reported alcohol consumption (SMD 0.07;95\%-CI -0.02-0.16), despite improving screening (SMD 0.53;95\%-CI 0.28-0.78) and brief intervention delivery (SMD 0.64;95\%-CI 0.27-1.02). Multifaceted strategies, i.e. professional and/or organisational and/or patient oriented strategies, seemed to have strongest effects on patients' alcohol consumption ( $\mathrm{p}<0.05$, compared to professional oriented strategies alone). Regarding SBI delivery, combining professional with patient oriented implementation strategies had the highest impact $(\mathrm{p}<0.05)$. Involving other staff besides physicians was beneficial for screening $(\mathrm{p}<0.05)$.

Conclusions Strategies should include a combination of patient, professional and organisational oriented implementation approaches and involvement of mid-level professions as well as physicians. Evidence for a new and innovative combination of multiple implementation approaches to increase alcohol focused SBI uptake in PHC, is required. 


\section{Introduction}

Worldwide, heavy alcohol consumption is a leading cause of ill-health and premature death (1). World Health Organization (WHO) recommends that health professionals provide alcohol screening, brief interventions, counselling and, when necessary, pharmacotherapy for heavy drinkers (2). There is a wealth of evidence in primary health care (PHC) for the effectiveness of alcohol screening and brief interventions (SBI) in adults (3-6). Previous research demonstrates that SBI is effective in various groups, either for identification of risky drinking, alcohol use disorders, excluding addicted patients, and for those who are not seeking treatment for alcohol-related problems (6-9). Brief interventions to reduce heavy drinking are costeffective and could be widely available in PHC (3). However, SBI is underused with less than $10 \%$ of those who might benefit from SBI, receiving a brief intervention (10). Large-scale studies that have attempted to increase the uptake of brief interventions have shown that implementing brief interventions in PHC remains difficult (11-13).

Studies that address the issue of integrating evidence into practice are referred to as ‘implementation research' (14). Changing provider behaviour and implementing new programs or innovations into practice could be achieved by various implementation strategies, as shown in the broader implementation literature (15-17). Promisingly, an increasing number of implementation studies are being conducted in the field of PHC-based alcohol prevention. In the last decade, three reviews have summarised the evidence to enhance the implementation of SBI in PHC (18-20). These reviews found that the effectiveness of multi-component implementation programmes on SBI delivery showed the most promising results (20). Effectiveness of implementation strategies on SBI delivery generally increased with the intensity of the intervention effort (19). Furthermore, it is suggested that nurses and other midlevel professionals, besides physicians, can enhance the uptake of SBI in PHC (21-23).

However, current literature provides little practical guidance on how to improve implementation. The impact of SBI on patients' alcohol consumption has been studied in many trials (e.g. $(11,24,25))$, but earlier systematic reviews did not provide practical guidance in how to increase SBI uptake in practice $(4,6,7,26)$. More insight is needed on how the uptake of SBI in PHC practice can be increased to contribute to health benefits. Therefore, the current review aims to identify effective SBI implementation strategies that 1) reduce heavy drinking and 2) increase SBI delivered in PHC. The review will also ask if involving nurses and other professionals has a positive impact in improving SBI delivery and decreasing patient alcohol consumption. 


\section{Methods}

This review is reported according to the Preferred Reporting Items for Systematic Reviews and Meta-Analysis (PRISMA) standards (27). The review protocol is available from http://www.odhinproject.eu/resources/documents/cat_view/3-odhin-project-documents/6technical-reports-and-deliverables.html.

We followed the Cochrane Effective Practice and Organisation of Care (EPOC) criteria, which define implementation strategies as "interventions designed to improve professional practice and the delivery of effective health services". EPOC offers guidance on conducting reviews of interventions that improve professional practice and delivery of effective health services. To connect this study to broader implementation research, we used the EPOC search strategy, the EPOC template for data extraction, and the EPOC taxonomy to categorise implementation strategies, and their checklist for quality appraisal (28).

\section{Data sources and searches}

The following computerised databases were searched since onset until May 2013: MEDLINE, EMBASE, Cinahl and Cochrane Central Register of Controlled Trials (CENTRAL). The search strategy is listed in Appendix 1. In addition, reference lists of relevant review articles and books were screened, and global experts in the field were contacted in order to identify grey literature and recent published studies not yet indexed.

\section{Study selection}

Two reviewers (MK and ML) independently screened relevant titles and abstracts. Full text copies of potentially relevant studies were then obtained and independently screened for inclusion by the same two reviewers. Disagreements between the reviewers were resolved through discussion, or a third reviewer was contacted to make the final decision (PA or IVDG).

In order to be included, a study had to meet the following PICO criteria (27): first, it had to be focused on a PHC setting; second, it had to include implementation strategies that were compared with a control group (usually defined as care as usual); third, it had to address decreasing heavy alcohol consumption, and/or cost outcomes, and/or increasing screening, and/or increasing brief interventions, but not alcohol dependence as defined by WHO (29) and 
the ICD-10 Classification of Mental and Behavioural Disorders (30); and, fourth, it had to be a controlled trial with an English or Dutch language full text copy available.

Effectiveness studies, e.g. examining the effectiveness of a 5-minute brief intervention compared to a 15-minute brief intervention, were excluded as they did not evaluate implementation strategies as defined by EPOC.

\section{Data extraction and quality assessment}

Data for each included study were extracted on: participants, setting, methods, SBI procedures, method of strategy, outcomes (alcohol consumption, screening, brief intervention, costs) and methodological quality. Implementation strategies were first classified into one of the following categories of the EPOC taxonomy: professional, financial, organisational, structural and regulatory interventions (http://epoc.cochrane.org/epoc-taxonomy); and, second, implementation strategies were classified into the EPOC elements, such as audit and feedback within professional oriented strategies (28). Two reviewers in different combinations (MK, MBAS, DNB, EK, PA, ML, JB, and IVDG) independently extracted the data. Any disagreement was resolved by discussion or by asking a third reviewer (from the review team) when consensus was not reached between the two reviewers.

Methodological quality of each paper was assessed by both reviewers using the EPOC checklist for quality criteria (28). Quality assessment was based on concealment of allocation, presence of professionals' behaviour or patient outcomes (alcohol consumption), follow-up, blinded assessment of primary outcome, baseline measurement of primary outcome, reliable (objective) primary outcome measures and protection against contamination. Any disagreement on fulfilling the criteria was resolved by discussion. Inclusion of studies was not influenced by methodological quality.

\section{Data synthesis and analysis}

All study outcomes were categorised by alcohol consumption, screening and/or brief interventions or costs, and type of implementation strategy.

Methods described by the Cochrane Collaboration were followed (31).

First, to identify effects of implementation strategies on the key outcomes, included studies were pooled with MetaEasy version 1.0.4 (32). Standardised mean differences (SMD) were calculated, both for dichotomous and continuous outcomes. Due to heterogeneity of included studies, we estimated effect sizes using a random-effects model based on DerSimonian and Laird's (DL) approach (33). 
Second, effect sizes of predictor measures, such as single versus multiple strategies, were calculated by meta-regression analyses. One advantage of such an approach is that, in case of no overall statistical effect being found from pooled studies, the regression allows distinction between effective and ineffective predictor measures. The predictor measures comprised 1) use of a single implementation strategy versus the use of multiple implementation strategies; 2) the type of implementation strategy as categorised by EPOC taxonomy (28), e.g. professional oriented strategies, such as audit and feedback, or organisational oriented strategies, such as task substitution; 3) whether or not the programme included multiple elements within their implementation strategy; 4) study duration $\leq 12$ months versus study duration $>12$ months; and, 5) whether the implementation strategies were focused on physician-only or those including nurses and other mid-level professionals. As instructed for fixed-effects meta-regression, we used weighted least squares regression, weighted by the inverse of the variance to identify relationships between predictors in explaining effect sizes (34). A random-effects metaregression was attempted, but did not converge. The cause of non-convergence was that the random effects of the predictors involved could not be estimated (probably because the number of studies was not sufficient to distinguish predictor random effects different from 0). Metaregression was applied with use of SPSS version 20 [IBM SPSS Statistics, USA].

\section{Results}

\section{Search results}

Our literature search identified 4,594 citations, of which 3,968 unique titles and abstracts were screened (figure 1). The full paper sift included 211 papers. Included in this were eight published papers that were identified by manual review of the reference lists of the studies and consultation of global experts. In the second sift, reasons for exclusion were design failures $(n=83)$, setting failures $(n=42)$, not being focused on implementation $(n=24)$ and not including alcohol consumption or SBI outcomes ( $n=29)$. Thirty-five papers, reporting on 29 studies were included in the final analysis.

\section{[INSERT FIGURE 1 ABOUT HERE]}

\section{Methodological quality}

All included studies were randomised controlled trials (RCT) (86\%) or controlled clinical trials (CCT) (14\%) (table 1). Concealment of allocation was not reported in eight studies (28\%) and 
was not clear in seven studies (24\%). In eight studies (28\%), substantial differences across study groups were found, or no baseline measurements of primary outcomes were reported. Protection against contamination was not addressed in eleven studies (38\%) and not clear in five studies $(17 \%)$.

\section{[INSERT TABLE 1 ABOUT HERE]}

\section{Study characteristics}

Most studies were carried out in the United States, followed by Australia/New Zealand, Europe, and Canada (table 2). Participating professionals were physicians (16 studies), or physicians in combination with other PHC staff such as nurses (5 studies), nurse practitioners (2 studies), physician assistants (1 study), practice assistants (1 study) or other health professionals ( 1 study). In the remaining studies the profession of participating professionals was not reported. In over a half of studies (55\%), the age of the patient groups ranged between 30-69 years. Other patient characteristics were not reported.

The included studies varied in applied implementation strategies and elements (table 1). The majority of studies $(\mathrm{n}=11)$ applied solely professional oriented implementation strategies (25, 35-44). Most common elements were educational meetings $(n=6)$, educational outreach visits $(n=5)$ and audit and feedback $(n=4)$. Three studies reported only organisational oriented strategies in which two applied a change in the scope and nature of benefits and services (45, 46), and one applied a change in the service delivery due to counselling by phone (47). One further study reported a patient oriented strategy, which consisted of printed educational materials for patients (48). In addition, six studies reported a combination of professional oriented and organisational oriented implementation strategies, in which in all educational meetings were applied, combined with either changes in medical record systems, formal integration of services or skill mix changes (49-54). Eight studies reported various combinations of professional oriented, organisational oriented, patient oriented and financial oriented strategies $(11,23,24,55-59)$.

Nineteen studies reported patient alcohol consumption outcomes (11, 23, 24, 35, 38, 43 $45,47,48,50-53,55-59)$. Studies reported one or more professional-related outcomes, that is: screening rate $(n=12)(11,25,35-37,39-42,46,49,54)$ and brief intervention $(B I)$ rate $(n=13)$ $(11,23,25,37-43,46,49,50)$. Only two studies reported outcomes related to costs or costeffectiveness (table 3$)(40,41)$. 


\section{[INSERT TABLE 2 ABOUT HERE]}

\section{[INSERT TABLE 3 ABOUT HERE]}

\section{Elements of effective implementation strategies}

Twenty-six studies were pooled and 24 studies were included in the meta-regression.

\section{Effects on alcohol consumption}

Of the 19 studies reporting on alcohol consumption, 15 were pooled for an overall effect size $(11,23,24,44,45,47,48,50-53,56-59)$. Due to substantial heterogeneity $\left(I^{2}=86 \%\right)$, we applied a random effects model. The random effects model showed no statistically significant effect of the pooled estimate of implementation strategies on alcohol consumption (SMD DL model -0.02; 95\%-CI -0.17 - 0.14) (figure 2). One study, Kypri et al 2004 (59) identified very strong opposite effects in a negative direction, meaning increased alcohol consumption, which was different to most other included studies. This could be due to the unique outcome measure used in the study (alcohol consumption in the last two weeks), whereas the rest of the studies reported on changes in drinking classification, AUDIT screening test scores, or mean weekly alcohol consumption, which are more representative measures. Using a post-hoc analysis without Kypri et al 2004 resulted in decreased heterogeneity $\left(\mathrm{I}^{2}=56 \%\right)$. Still, no significant difference in pooled effect was found, compared to control groups (SMD DL model 0.07; 95\%CI $-0.02-0.16$ ) (figure 2). However, the remaining heterogeneity can be primarily explained by the type of implementation strategy, as presented from the meta-regression results in table 4 (omitting Kypri et al 2004). Table 4 shows that combinations of professional, organisational and patient oriented strategies were significantly more effective at decreasing patients' alcohol consumption than solely professional oriented implementation strategies (table 4).

\section{[INSERT FIGURE 2 ABOUT HERE]}

\section{[INSERT TABLE 4 ABOUT HERE]}

\section{Effects on SBI}

Of the twelve studies with outcomes on screening, ten provided sufficient data for pooling (11, $25,35-37,39,42,46,49,54)$. Due to high heterogeneity $\left(\mathrm{I}^{2}=94 \%\right)$, we applied a random effects model (figure 3). Pooling showed that the implementation strategies increased screening 
delivery (SMD DL model 0.53; 95\%-CI 0.28-0.78). Wilson et al (1992) (46) showed the least positive effect and Adams et al (49) the strongest positive effect. Studies with significant effects included both physicians and other health professionals (such as nurses) in screening for alcohol consumption more so than studies with little effect.

The meta-regression analysis (table 5) showed that multiple types of implementation strategies (e.g. professional combined with organisational oriented implementation strategies) were more effective in changing behaviour compared to a single implementation strategy (e.g. only a professional oriented implementation strategy). Furthermore, we found that combining professional and patient oriented strategies was more effective than only professional oriented strategies. Lastly, involving nurses and other mid-level professionals as well as physicians in implementation strategies, showed statistically significant higher effects than focusing on physicians only.

\section{[INSERT FIGURE 3 ABOUT HERE]}

\section{[INSERT TABLE 5 ABOUT HERE]}

With regard to the 13 studies that reported process outcomes on brief interventions, outcomes of nine studies were pooled $(11,25,37,41-43,46,49,50)$. These studies showed high heterogeneity $\left(\mathrm{I}^{2}=97 \%\right)$. Ferrer et al (2009) (50) was the only study in which patients had the opportunity to choose which lifestyle topic to tackle (alcohol, smoking, physical activity or diet). The majority of patients preferred to discuss lifestyle factors other than alcohol. This approach was judged to be substantially different from the other studies. Therefore this study was not included in the analysis and forest plot (figure 4). The forest plot shows that the implementation strategies resulted in increased brief intervention delivery (SMD DL model $0.64 ; 95 \%$-CI $0.27-1.02$ ).

The meta-regression analyses showed that multiple inclusion of implementation strategies was more effective than single types (table 6). Furthermore, the combination of professional and patient oriented implementation strategies, multiple component strategies and study duration of twelve months or more were of added value.

[INSERT FIGURE 4 ABOUT HERE]

[INSERT TABLE 6 ABOUT HERE] 


\section{Discussion}

This study aimed to identify implementation strategies that focused on increasing SBI uptake with an impact on patient alcohol consumption and/or SBI delivery in PHC. The predictor measures comprised: 1) use of a single implementation strategy versus the use of multiple implementation strategies; 2) the type of implementation strategy as categorised by EPOC taxonomy (28), e.g. professional oriented strategies such as audit and feedback, or organisational oriented strategies such as task substitution; 3) whether or not the programme included multiple elements within their implementation strategy; 4) study duration $\leq 12$ months versus study duration >12 months; and 5) whether the implementation strategies were focused on physicians or on nurses and other mid-level professionals as well.

From the meta-analysis, it can be concluded that with all implementation strategies pooled, there was a lack of statistically significant impact on patients' self-reported alcohol consumption, although professional SBI behaviour improved. However, those specific studies that combined two of the professional, patient and organisational implementation strategies were significantly more effective in reducing alcohol consumption than solely professional oriented implementation strategies. This shows that it does matter which implementation strategy is selected. Regarding screening, combining professional with patient oriented strategies and involving primary health care staff besides physicians (e.g. nurses as well as physicians), led to increased activity. In terms of brief intervention delivery, implementation strategies had more effect when multiple components of different implementation strategies were applied, for example combining educational outreach visits (professional oriented) with patient self-management education materials (patient oriented).

In line with the wider alcohol-related literature, our study confirms that multicomponent programs seemed to be the most promising implementation strategies (20). Our study added to this finding by identifying specific predictor variables for successfully changing provider SBI activity or patients' alcohol consumption behaviour, such as effectiveness of combining professional and patient oriented strategies. Similar to Nilsen et al (19) and Williams et al (18), this present study showed that the implementation strategy effectiveness generally increased with the intensity of the implementation effort, a finding different from general implementation research (60). We have added to this general finding by identifying elements that made the implementation strategies more effective, such as combining professional, patient and organisational implementation strategies. 
Furthermore, the present study demonstrates that, in order to increase screening behaviour, involving nurses and other mid-level professionals is more effective than focusing only on physicians delivering the screening, which is in line with other studies in $\operatorname{PHC}(21,22$, $61)$.

Whereas reviews (3-7) find significant reductions in alcohol consumption from implemented SBI, this positive effect was not found in our meta-analyses, which focused on strategies to increase SBI uptake and not on SBI effectiveness itself (62). We found that multiple implementation approaches have a significant impact in increasing SBI delivery, but not on reducing patient alcohol consumption. The marginal benefits of additional services provided through multiple implementation approaches are low. Therefore, new and innovative combinations of multiple implementation approaches are required to increase SBI uptake in primary health care. It is possible that the delivered brief interventions might have been suboptimal in the included studies, resulting in less reduction in patients' alcohol consumption as potentially could be achieved (63). Low fidelity in delivering lifestyle-changing interventions have been reported in several other studies $(61,64,65)$. However, we were not able to correct for this assumption as included studies did not report on fidelity of the intervention. Finally, another reason for failing to find effects of implementation strategies on alcohol consumption is that studies may have lacked sufficient power to detect significant differences; we found that half of the included studies did not report on or achieve sufficient power.

A strength of our study includes the categorisation of interventions defined by the EPOC taxonomy of interventions (28), as uniform analysing and reporting methods prevents confusion about terminology, and contributes to the evidence base of implementation strategies (16). There are alternatives to the pragmatically-funded EPOC taxonomy with more theoretical fundaments, including the Behaviour Change Wheel, Leeman Taxonomy and behaviour change techniques (66); however, these more recent developed taxonomies are based on the EPOC taxonomy (67).

Another strength of our study is that it is the first systematic review that included a metaregression analysis regarding implementation strategy outcomes on subsequent patient alcohol consumption. Nevertheless, the meta-analysis should be interpreted with caution as the standardised mean differences cannot give quantitative outcomes that could be easily translated into daily practice. Moreover, the studies included in this review often did not report sufficient details (on cost outcomes, on implementation strategies, on fidelity, on power calculations). We were unable to draw firm conclusions regarding the cost-effectiveness of different strategies - 
thus we propose the need for more health economic research. Similarly, implementation strategies were often poorly described in most of the included papers, a common finding in implementation trials (68), making it hard for reviewers to clearly identify and characterise effective elements of strategies. Finally, several sources of variation may have impacted on patient-level outcomes, such as different populations from different countries, variables that we were not able to include in the meta-regression. All studies with outcomes on patient alcohol consumption were pooled and showed no effect. It is important to bear in mind that this does not imply that implementation strategies cannot change alcohol consumption; rather, it suggests that it is important to purposefully select implementation strategies, as they may differ in effectiveness. For instance, combining patient and professional oriented strategies appears to be more effective compared to a professional oriented single strategy. Due to a lack of studies with common elements within the main categories of EPOC and a high heterogeneity of implementation strategies, we could only draw conclusions based on the main categories of EPOC's taxonomy of interventions (professional, organisational and patient oriented implementation strategies). Pooling of implementation strategy elements would have provided more precise information.

In conclusion, in order to increase SBI delivery and decrease patients' alcohol consumption, this study has shown that implementation should ideally include a combination of patient, professional and organisational oriented implementation strategies and involvement of other staff working with physicians. To explain the lack of effect on alcohol consumption when SBI delivery was increased, the fidelity of SBI delivery to detect effects in patient's alcohol consumption should be investigated. Furthermore, evidence for new and innovative combinations of multiple implementation approaches to increase alcohol focused SBI uptake in $\mathrm{PHC}$, is required. 


\section{References}

1. WHO REgIONAL OFFICE FOR EUROPE. Alcohol in the European Union. Consumption, harm and policy approaches. In: Anderson P., Møller L. \& Galea G., editors, Copenhagen: WHO Regional Office for Europe; 2012.

2. WORLD HEALTH ORGANIZATION. Global status report on alcohol and health 2014: World Health Organization; 2014.

3. WilK A. I., JENSEN N. M., HAVIGHURST T. C. Meta-analysis of randomized control trials addressing brief interventions in heavy alcohol drinkers, J Gen Intern Med 1997: 12: 274-283.

4. Jonas D. E., Garbutt J. C., Amick H. R., Brown J. M., Brownley K. A., Council C. L. et al. Behavioral counseling after screening for alcohol misuse in primary care: a systematic review and meta-analysis for the U.S. Preventive Services Task Force, Ann Intern Med 2012: 157: 645-654.

5. BRAY J. W., COWEll A. J., Hinde J. M. A systematic review and meta-analysis of health care utilization outcomes in alcohol screening and brief intervention trials, Med Care 2011: 49: 287-294.

6. Bertholet N., Daeppen J. B., Wietlisbach V., Fleming M., Burnand B. Reduction of alcohol consumption by brief alcohol intervention in primary care: systematic review and meta-analysis, Arch Intern Med 2005: 165: 986-995.

7. Kaner E. F., Beyer F., Dickinson H. O., PienaAr E., CAMPbell F., Schlesinger C. et al. Effectiveness of brief alcohol interventions in primary care populations, Cochrane database of systematic reviews (Online) 2007: CD004148.

8. Moyer A., Finney J. W., SWEARINGEN C. E., VERgun P. Brief interventions for alcohol problems: a meta-analytic review of controlled investigations in treatmentseeking and non-treatment-seeking populations, Addiction (Abingdon, England) 2002: 97: 279-292.

9. Moyer V. A., Preventive SERvices TASK F. Screening and behavioral counseling interventions in primary care to reduce alcohol misuse: U.S. preventive services task force recommendation statement, Ann Intern Med 2013: 159: 210-218.

10. Drummond C., Wolstenholme A., Deluca P., DAVEy Z., DONOGhUe K., Elzerbi C. et al. Alcohol interventions and treatment in Europe. In: Anderson P, Braddick F, Reynolds J \& A G., editors. Alcohol Policy in Europe: Evidence from AMPHORA; 2013.

11. VAn Beurden I., Anderson P., AkKermans R. P., T. M P., Wensing M., H. Involvement of general practitioners in managing alcohol problems: a randomized controlled trial of a tailored improvement programme, Addiction (Abingdon, England) 2012: 107: 1601-1611.

12. ANDERSON P. Overview of interventions to enhance primary-care provider management of patients with substance-use disorders, Drug Alcohol Rev 2009: 28: 567-574.

13. Kaner E., Bland M., Cassidy P., Coulton S., Dale V., Deluca P. et al. Effectiveness of screening and brief alcohol intervention in primary care (SIPS trial): pragmatic cluster randomised controlled trial, BMJ 2013: 346: e8501.

14. ECCLES M. P., S. M. B. Welcome to Implementation Science, Implement Sci 2006: 1. 15. Grimshaw J. M., Eccles M. P., Lavis J. N., Hill S. J., SQuires J. E. Knowledge translation of research findings, Implement Sci 2012: 7: 50.

16. Grimshaw J. M., Shirran L., Thomas R., Mowatt G., Fraser C., Bero L. et al. Changing provider behavior: an overview of systematic reviews of interventions, Med Care 2001: 39: II2-45. 
17. BoAZ A., BAEZA J., Fraser A., EUROPEAN IMPLEMENTATION SCORE COLLABORATIVE G. Effective implementation of research into practice: an overview of systematic reviews of the health literature, BMC research notes 2011: 4: 212.

18. Williams E. C., Johnson M. L., Lapham G. T., Caldeiro R. M., CheW L., Fletcher G. S. et al. Strategies to implement alcohol screening and brief intervention in primary care settings: a structured literature review, Psychology of addictive behaviors : journal of the Society of Psychologists in Addictive Behaviors 2011: 25: 206-214.

19. Nilsen P., AAlto M., BendTSEn P., SePPA K. Effectiveness of strategies to implement brief alcohol intervention in primary healthcare. A systematic review, Scandinavian journal of primary health care 2006: 24: 5-15.

20. Anderson P., LAurant M., Kaner E., Wensing M., Grol R. Engaging general practitioners in the management of hazardous and harmful alcohol consumption: results of a meta-analysis, Journal of studies on alcohol 2004: 65: 191-199.

21. Laurant M., Harmsen M., Wollersheim H., Grol R., FABer M., SibBald B. The impact of nonphysician clinicians: do they improve the quality and cost-effectiveness of health care services?, Medical care research and review : MCRR 2009: 66: 36S89S.

22. Rashidian A., Shakibazadeh E., Karimi- Shahanjarini A., Glenton C., Noyes J., LEWIN S. et al. Barriers and facilitators to the implementation of doctor-nurse substitution strategies in primary care: qualitative evidence synthesis. Cochrane Database of Systematic Reviews: John Wiley \& Sons, Ltd; 2013.

23. Drevenhorn E., Bengtson A., Nilsson P. M., Nyberg P., KJEllgren K. I. Consultation training of nurses for cardiovascular prevention A randomized study of 2 years duration, Blood Pressure 2012: 21: 293-299.

24. Kypri K., LANGley J. D., SAunders J. B., CASHEll-SMith M. L., Herbison P. Randomized controlled trial of web-based alcohol screening and brief intervention in primary care, Archives of Internal Medicine 2008: 168: 530-536.

25. Rose H. L., Miller P. M., Nemeth L. S., Jenkins R. G., Nietert P. J., Wessell A. M. et al. Alcohol screening and brief counseling in a primary care hypertensive population: a quality improvement intervention, Addiction (Abingdon, England) 2008: 103: $1271-1280$.

26. O'Donnell A., Anderson P., Newbury-Birch D., Schulte B., Schmidt C., Reimer J. et al. The impact of brief alcohol interventions in primary healthcare: a systematic review of reviews, Alcohol and alcoholism (Oxford, Oxfordshire) 2014: 49: 66-78.

27. Moher D., Liberati A., TetZlaff J., Altman D. G., Group P. Preferred reporting items for systematic reviews and meta-analyses: the PRISMA statement, Ann Intern Med 2009: 151: 264-269, W264.

28. Bero LA, Grilli R, Grimshaw JM, Mowatt G, Oxman AD, Zwarenstein M. Cochrane Effective Practice and Organisation of Care Group. The Cochrane Library, Oxford, England; 2002.

29. BAbor T, CAMpbell R, Room R, SAunders J. Lexicon of Alcohol and Drug Terms, Geneva, Switzerland: World Health Organization; 1994.

30. World Health ORGANIZATION. The ICD-10 Classification of Mental and Behavioral Disorders: Diagnostic Criteria for Research. In: World Health Organization, editor, Geneva, Switzerland; 1992.

31. Higgins JP, GREen S. Cochrane Handbook for Systematic Reviews of Interventions: Version 5.0.1., 2008.

32. E K., REEVES D. MetaEasy: A Meta-Analysis Add-In for Microsoft Excel, Journal of Statistical Software 2009: 30. 
33. PetTiti D. Approaches to heterogeneity in meta-analysis., Statistics in Medicine 2001: 30: 3625-3633.

34. THOMPSON S.G. Why and how sources of heterogeneity should be investigated. In: Egger M, Davey-Smith G \& Altman DG, editors. Systematic Reviews in Health Care: Meta-Analysis in Context, London, England; 2001, p. 157-175.

35. Bonevski B., SAnson-Fisher R. W., CAMpbell E., CARruthers A., Reid A. L., IRELAND M. Randomized controlled trial of a computer strategy to increase general practitioner preventive care. Preventive medicine; 1999, p. 478-486.

36. Borgiel AE, Williams Ji, Davis DA, Dunn EV, HobBs N, Hutchison B et al. Evaluating the effectiveness of 2 educational interventions in family practice, CMAJ 1999: 161: 965-970.

37. Bradley K. A., Epler A. J., Bush K. R., Sporleder J. L., Dunn C. W., Cochran N. E. et al. Alcohol-related discussions during general medicine appointments of male VA patients who screen positive for at-risk drinking, Journal of General Internal Medicine 2002: 17 (5): 315-326.

38. Chossis I., Lane C., Gache P., Michaud P. A., Pécoud A., Rollnick S. et al. Effect of training on primary care residents' performance in brief alcohol intervention: a randomized controlled trial. Journal of general internal medicine; 2007, p. 1144-1149.

39. Friedmann P. D., Rose J., HAYAKi J., RAmSEy S., Charuvastra A., Dube C. et al. Training primary care clinicians in maintenance care for moderated alcohol use, Journal of General Internal Medicine 2006: 21 (12): 1269-1275.

40. FunK M, WutzKe S, KANer E, ANDERson P, PAs L, MCCORMick R et al. A multicountry controlled trial of strategies to promote dissemination and implementation of brief alcohol intervention in primary health care: findings of a World Health Organization collaborative study, J Stud Alcohol 2005: 66: 379-388.

41. KANER E, Lock C, HeAther N, MCNAMEe P, Bond S. Promoting brief alcohol intervention by nurses in primary care: a cluster randomised controlled trial, Patient Educ Couns 2003: 51: 277-284.

42. LOCKYER J., El-GuebAly N., SimPSON E., GROMOFF B., TOEWs J., JusChKA B. Standardized patients as a measure of change in the ability of family physicians to detect and manage alcohol abuse. Academic medicine : journal of the Association of American Medical Colleges; 1996, p. S1-3.

43. Saitz R., Horton N. J., Sullivan L. M., Moskowitz M. A., Samet J. H. Addressing alcohol problems in primary care: A cluster randomized, controlled trial of a systems intervention - The screening and intervention in primary care (SIP) study, Annals of Internal Medicine 2003: 138 (5): 372-382.

44. Williams E. C., Achtmeyer C. E., Kivlahan D. R., Greenberg D., Merrill J. O., WICKIZER T. M. et al. Evaluation of an electronic clinical reminder to facilitate brief alcohol-counseling interventions in primary care, Journal of Studies on Alcohol \& Drugs 2010: 71: 720-725.

45. VINSON D. C., DEVERA-SALES A. Computer-generated written behavioral contracts with problem drinkers in primary medical care, Substance Abuse 2000: 21: 215-222.

46. Wilson A., MCDONALD P., HAYES L., COONEY J. Health promotion in the general practice consultation: a minute makes a difference. BMJ (Clinical research ed); 1992, p. 227-230.

47. Brown R. L., Saunders L. A., Bobula J. A., Mundt M. P., Koch P. E. Randomizedcontrolled trial of a telephone and mail intervention for alcohol use disorders: Threemonth drinking outcomes, Alcoholism: Clinical and Experimental Research 2007: 31 (8): 1372-1379. 
48. Wang T. C., Kyriacou D. N., Wolf M. S. Effects of an intervention brochure on emergency department patients' safe alcohol use and knowledge, Journal of Emergency Medicine 2010: 39: 561-568.

49. AdAMS A., OCKENE J. K., WheEler E. V., Hurley T. G. Alcohol counseling: Physicians will do it, Journal of General Internal Medicine 1998: 13 (10): 692-698.

50. Ferrer R. L., Mody-BAIley P., JAÉN C. R., GotT S., Araujo S. A medical assistantbased program to promote healthy behaviors in primary care, Annals of Family Medicine 2009: 7: 504-512.

51. Oslin D. W., Grantham S., Coakley E., MaXwell J., Miles K., Ware J. et al. PRISM-E: comparison of integrated care and enhanced specialty referral in managing at-risk alcohol use. Psychiatric services (Washington, DC); 2006, p. 954-958.

52. Oslin D. W., Sayers S., Ross J., Kane V., Ten Have T., Conigliaro J. et al. Disease Management for Depression and At-Risk Drinking Via Telephone in an Older Population of Veterans, Psychosomatic Medicine 2003: 65 (6): 931-937.

53. ReIFF-HeKKING S., OCKENE J. K., HuRley T. G., ReED G. W. Brief physician and nurse practitioner-delivered counseling for high-risk drinking: Results at 12-month follow-up, Journal of General Internal Medicine 2005: 20 (1): 7-13.

54. RODNEY W. M., NUTTER D., WIDOFF B. Recording patients' consumption of social drugs in a family medicine residency: a longitudinal study. Family practice; 1985, p. 86-90.

55. Helzer J. E., Rose G. L., Badger G. J., Searles J. S., Thomas C. S., Lindberg S. A. et al. Using interactive voice response to enhance brief alcohol intervention in primary care settings, Journal of studies on alcohol and drugs 2008: 69: 251-258.

56. Butler S. F., Chiauzzi E., Bromberg J. I., Budman S. H., Buono D. P. Computerassisted screening and intervention for alcohol problems in primary care, Journal of Technology in Human Services 2003: 21: 1-19.

57. Fink A., Elliott M. N., Tsai M., BeCK J. C. An evaluation of an intervention to assist primary care physicians in screening and educating older patients who use alcohol.[Erratum appears in J Am Geriatr Soc. 2008 Jun;56(6):1165], Journal of the American Geriatrics Society 2005: 53: 1937-1943.

58. KYPRI K., MCANALLY H. M. Randomized controlled trial of a web-based primary care intervention for multiple health risk behaviors, Preventive medicine 2005: 41 (3-4): 761-766.

59. Kypri K., SAunders J. B., Williams S. M., McGee R. O., LANGley J. D., CASHellSMITH M. L. et al. Web-based screening and brief intervention for hazardous drinking: A double-blind randomized controlled trial, Addiction (Abingdon, England) 2004: 99 (11): 1410-1417.

60. Squires J. E., SUllivan K., ECCles M. P., Worswick J., Grimshaw J. M. Are multifaceted interventions more effective than single-component interventions in changing health-care professionals' behaviours? An overview of systematic reviews, Implement Sci 2014: 9: 152.

61. CARLFJORD S., LindBERG M., ANDERSSON A. Staff perceptions of addressing lifestyle in primary health care: a qualitative evaluation 2 years after the introduction of a lifestyle intervention tool, BMC family practice 2012: 13: 99.

62. Rabin B. A., Brownson R. C., Haire-Joshu D., Kreuter M. W., WeAver N. L. A glossary for dissemination and implementation research in health, Journal of public health management and practice : JPHMP 2008: 14: 117-123.

63. Bartholomew LK, Parcel GS, KoK G, Gottlieb N, M. F. Planning Health Promotion Programs: An Intervention Mapping Approach San Fransisco, CA: JosseyBass; 2011. 
64. Holmberg C., Sarganas G., Mittring N., Braun V., Dini L., Heintze C. et al. Primary prevention in general practice - views of German general practitioners: a mixed-methods study, BMC family practice 2014: 15: 103.

65. Avery L., Flynn D., van Wersch A., SniehotTa F. F., Trenell M. I. Changing physical activity behavior in type 2 diabetes: a systematic review and meta-analysis of behavioral interventions, Diabetes care 2012: 35: 2681-2689.

66. Colquhoun H., LeEMAN J., Michie S., LOKKer C., BragGe P., HeMPel S. et al. Towards a common terminology: a simplified framework of interventions to promote and integrate evidence into health practices, systems, and policies, Implement Sci 2014: 9: 51.

67. Mazza D., Bairstow P., Buchan H., Chakraborty S. P., Van Hecke O., Grech C. et al. Refining a taxonomy for guideline implementation: results of an exercise in abstract classification, Implement Sci 2013: 8: 32.

68. Proctor E. K., Powell B. J., MCMillen J. C. Implementation strategies: recommendations for specifying and reporting, Implement Sci 2013: 8: 139.

69. LOCK C. A., KANER E. F. Use of marketing to disseminate brief alcohol intervention to general practitioners: promoting health care interventions to health promoters, Journal of evaluation in clinical practice 2000: 6: 345-357.

70. Gomel M. K., WutZKe S. E., HARdCASTle D. M., LAPSLEy H., ReZnik R. B. Costeffectiveness of strategies to market and train primary health care physicians in brief intervention techniques for hazardous alcohol use, Social science \& medicine (1982) 1998: 47: 203-211.

71. Kaner E. F., Lock C. A., McAvoy B. R., HeAther N., Gilvarry E. A RCT of three training and support strategies to encourage implementation of screening and brief alcohol intervention by general practitioners, The British journal of general practice : the journal of the Royal College of General Practitioners 1999: 49: 699-703.

72. OCKene J. K., AdAms A., Hurley T. G., WheEler E. V., Hebert J. R. Brief physician- and nurse practitioner-delivered counseling for high-risk drinkers: does it work?, Arch Intern Med 1999: 159: 2198-2205.

73. Drevenhorn E., Bengtson A., Allen J. K., SÄljö R., KJellgren K. I. Counselling on lifestyle factors in hypertension care after training on the stages of change model. European journal of cardiovascular nursing : journal of the Working Group on Cardiovascular Nursing of the European Society of Cardiology; 2007, p. 46-53.

74. Hilbink M., Voerman G., VAn Beurden I., PenninX B., LaURANT M. A randomized controlled trial of a tailored primary care program to reverse excessive alcohol consumption, Journal of the American Board of Family Medicine 2012: 25: 712-722. 


\section{Acknowledgements}

We would like to acknowledge Steven Teerenstra (Statistician, at the Department of Health Evidence Radboud university medical center) and Rogier Donders (Statistician, at the Department of Health Evidence Radboud university medical center) who assisted the authors in conducting the meta-regression analysis. 


\section{Legends for Figures}

Figure 1: Flow chart of study selection

Figure 2: Random effects meta-analysis of studies with alcohol consumption outcomes*

* Excluding Kypri et al, 2004

Figure 3: Random effects meta-analysis of studies with screening outcomes

Figure 4: Random effects meta-analysis of studies with brief intervention outcomes*

* Excluding Ferrer et al, 2009 


\section{Tables}

Table 1 Quality scores of included studies, based on Cochrane Effective Practice and Organisation of Care checklist

\begin{tabular}{|c|c|c|c|c|c|c|c|c|}
\hline Author year & $\begin{array}{l}\text { Power } \\
\text { calculation } \\
\text { reported and } \\
\text { sufficient }\end{array}$ & $\begin{array}{l}\text { Unit of } \\
\text { Allocation is } \\
\text { unit of } \\
\text { analysis or } \\
\text { statistical } \\
\text { correction for } \\
\text { clustering }\end{array}$ & $\begin{array}{l}\text { Concealment } \\
\text { of allocation }\end{array}$ & $\begin{array}{l}\text { Follow-up of } \\
\text { professionals/ } \\
\text { patients } \\
\text { achieved }\end{array}$ & $\begin{array}{l}\text { Blinded } \\
\text { assessment of } \\
\text { primary } \\
\text { outcome(s) }\end{array}$ & $\begin{array}{l}\text { Baseline } \\
\text { measurement } \\
\text { of primary } \\
\text { outcome(s) }\end{array}$ & $\begin{array}{l}\text { Reliable } \\
\text { primary } \\
\text { outcome } \\
\text { measures }\end{array}$ & $\begin{array}{l}\text { Protection } \\
\text { against } \\
\text { contaminatio } \\
\mathrm{n}\end{array}$ \\
\hline Adams 1998 & Not done & Done & Not clear & Not clear & Done & Not clear & Not clear & Not clear \\
\hline $\begin{array}{l}\text { Beurden van } \\
2012\end{array}$ & Not clear & Done & Done & Not done & Done & Done & Not done & Done \\
\hline $\begin{array}{l}\text { Bonevski } \\
1999 \\
\end{array}$ & Done & Done & Done & Done & Not done & Done & Not done & Done \\
\hline Borgiel 1999 & Done & Not clear & Done & Done & Not done & Done & Not done & Not done \\
\hline Bradley 2002 & Not done & Not done & Not clear & Not done & Done & Not done & Not clear & Done \\
\hline Brown 2007 & Done & Not done & Done & Done & Done & Done & Not clear & Not done \\
\hline Butler 2003 & Not done & Not done & Not done & Not clear & Not done & Done & Not done & Done \\
\hline Chossis 2007 & Not clear & Done & Done & Done & Not done & Done & Not done & Not clear \\
\hline $\begin{array}{l}\text { Drevenhorn } \\
2012\end{array}$ & Done & Not done & Not done & $\begin{array}{l}\text { Prof: not } \\
\text { done ; } \\
\text { patients: done }\end{array}$ & Not clear & Not done & Not clear & Not done \\
\hline Ferrer 2009 & Not done & Done & Done & Done & Not done & Not done & Done & Not done \\
\hline Fink 2005 & Not done & Done & Not clear & Done & Not done & Done & Done & Not clear \\
\hline $\begin{array}{l}\text { Friedmann } \\
2006\end{array}$ & Not done & Done & Not clear & Not clear & Not clear & Not clear & Not clear & Not done \\
\hline Funk 2005 & Done & Done & Done & Done & Not clear & Not done & Done & Done \\
\hline Helzer 2008 & Not done & Done & Not clear & Done & Not done & Done & Not clear & Not done \\
\hline
\end{tabular}




\begin{tabular}{|c|c|c|c|c|c|c|c|c|}
\hline Kaner 2003 & Done & Not done & Not done & Not done & Not done & Not done & Not clear & Done \\
\hline Kypri 2004 & Done & Done & Done & Done & Not done & Done & Done & Done \\
\hline Kypri 2005 & Done & Done & Done & Done & Done & Not clear & Done & Done \\
\hline Kypri 2008 & $\begin{array}{l}\text { Not done } \\
\text { (sample size } \\
\text { not achieved) }\end{array}$ & Done & Done & Done & Not done & Not clear & Not done & Not clear \\
\hline Lockyer 1996 & Not done & Done & Done & Done & Not done & Done & Not done & Not done \\
\hline Oslin 2003 & Not done & Done & Done & Done & Not clear & Done & Not clear & Done \\
\hline Oslin 2006 & Not done & Done & Not clear & Done & Done & Done & Done & Not clear \\
\hline $\begin{array}{l}\text { Reiff- } \\
\text { Hekking } \\
2005\end{array}$ & Done & Done & Not done & Done & Not done & Not clear & Not done & Done \\
\hline Rodney 1985 & Not done & Done & Not done & Not clear & Not done & Not done & Not clear & Not done \\
\hline Rose 2008 & Not done & Done & Not clear & Not clear & Not done & Done & Not done & Done \\
\hline Saitz 2003 & Done & Done & Done & Done & Not done & Done & Not clear & Done \\
\hline Vinson 2000 & Not done & Done & Not done & Done & Not done & Done & Not done & Done \\
\hline Wang 2010 & $\begin{array}{l}\text { Not done } \\
\text { (sample size } \\
\text { not achieved) }\end{array}$ & Done & Done & Not done & done & Not done & Not done & Not done \\
\hline Williams 201 & Not done & Not done & Not done & Done & Not clear & Not done & Done & Not done \\
\hline Wilson 1992 & Not done & Not done & Not done & Not done & Done & Done & Done & Not done \\
\hline
\end{tabular}


Table 2 Characteristics of included studies

\begin{tabular}{|c|c|c|c|c|c|}
\hline $\begin{array}{l}\text { Study, year } \\
\text { (ref) }\end{array}$ & $\begin{array}{l}\text { Design, study } \\
\text { duration }\end{array}$ & $\begin{array}{l}\text { Setting (country; } \\
\text { setting; type of } \\
\text { health care } \\
\text { professionals) }\end{array}$ & Participants & Implementation strategy (IS) vs Control & $\begin{array}{l}\text { Outcome type*: } \\
\text { Effect Size } \\
(95 \%-\text { CI })^{\#}\end{array}$ \\
\hline \multicolumn{6}{|c|}{ Professional oriented implementation strategies } \\
\hline $\begin{array}{l}\text { Bonevski } \\
1999(35)\end{array}$ & $\begin{array}{l}\text { RCT, study } \\
\text { duration assumed } \\
\text { to be } 5 \text { months }\end{array}$ & $\begin{array}{l}\text { - Australia } \\
\text { - Primary health } \\
\text { care practice } \\
\text { - GPs }\end{array}$ & $\begin{array}{l}\text { General practitioners } \\
\mathrm{N}=19 \\
\text { Patients } \mathrm{N}=575 \text { (Group } 1 \\
\mathrm{~N}=154 ; \text { Group } 2 \mathrm{~N}=143 ; \\
\text { Group } 3 \mathrm{~N}=138 ; \text { Group } 4 \\
\mathrm{~N}=140 \text { ) }\end{array}$ & $\begin{array}{l}\text { IS: Computerised feedback about: guidelines and consensus } \\
\text { standards of care, individual goals, calculated performance } \\
\text { rates. Practitioner feedback about patients' smoking status, } \\
\text { benzodiazepine use, blood pressure screening, cholesterol } \\
\text { screening, and the delivery of programme elements (Audit } \\
\text { and feedback) } \\
\text { Control: Usual care }\end{array}$ & $\begin{array}{l}\text { Screening: } \\
\mathrm{z}=2.3079 \\
(\mathrm{p}<0,02)\end{array}$ \\
\hline $\begin{array}{l}\text { Borgiel et al } \\
1999(36)\end{array}$ & $\begin{array}{l}\text { RCT, study } \\
\text { duration } 2 \text { years }\end{array}$ & $\begin{array}{l}\text { - Canada } \\
\text { - Primary health } \\
\text { care practice } \\
\text { - Physicians }\end{array}$ & $\begin{array}{l}\text { Family physicians } \mathrm{N}=56 \\
\text { (Intervention group } \mathrm{N}=29 \\
\text { Control group } \mathrm{N}=27 \text { ) }\end{array}$ & $\begin{array}{l}\text { IS: Practice assessment report, continuing Medical Education } \\
\text { with additional plan and follow-up visit by mentors (Audit } \\
\text { and feedback; educational meeting; educational outreach } \\
\text { visits) } \\
\text { Control: Usual care }\end{array}$ & $\begin{array}{l}\text { Screening: NR } \\
(p>0.05)\end{array}$ \\
\hline $\begin{array}{l}\text { Bradley et al } \\
2002(37)\end{array}$ & $\begin{array}{l}\text { CCT, study } \\
\text { duration } 6 \\
\text { months }\end{array}$ & $\begin{array}{l}\text { - United States } \\
\text { - Primary health } \\
\text { care practice } \\
\text { - Resident or } \\
\text { fellow MD, } \\
\text { Faculty/staff MD, } \\
\text { family nurse } \\
\text { practitioner }\end{array}$ & $\begin{array}{l}\text { General internal medicine } \\
\text { clinic } \mathrm{N}=17(6 \text { resident or } \\
\text { fellow MDs; } 6 \\
\text { faculty/staff MDs; } 5 \\
\text { family nurse } \\
\text { practitioners); Patients } \\
\mathrm{N}=47 \text { (Intervention group } \\
\mathrm{N}=17 \text {; Control group } \\
\mathrm{N}=30 \text { ) }\end{array}$ & 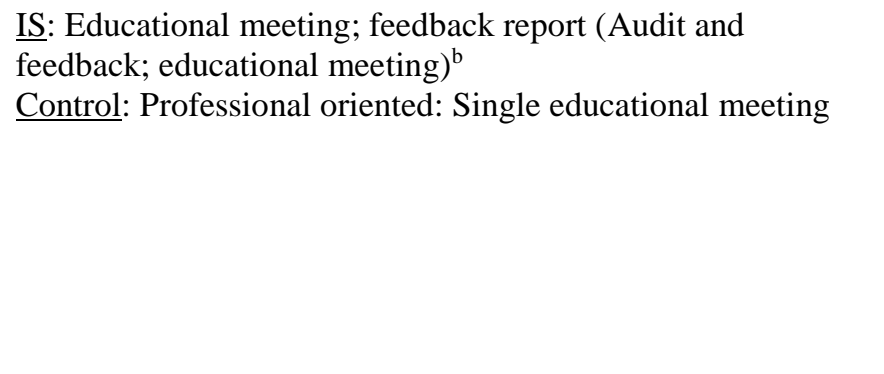 & $\begin{array}{l}\text { Screening: NR } \\
(\mathrm{p}<0.005) \\
\text { BI: NR } \\
(\mathrm{p}=0.035)\end{array}$ \\
\hline $\begin{array}{l}\text { Chossis et al } \\
2007 \text { (38) }\end{array}$ & $\begin{array}{l}\text { RCT, study } \\
\text { duration assumed } \\
\text { to be } 9 \text { months }\end{array}$ & $\begin{array}{l}\text { - Switzerland } \\
\text { - Outpatient clinic } \\
\text { (i.e. ambulatory } \\
\text { care provided by } \\
\text { specialists/ } \\
\text { hospitals) } \\
\text { - GPs }\end{array}$ & $\begin{array}{l}\text { Primary health care } \\
\text { residents } \mathrm{N}=26 \\
\text { (Intervention group } \mathrm{N}=13 \text {; } \\
\text { Control group } \mathrm{N}=13 \text { ) }\end{array}$ & $\begin{array}{l}\text { IS: Two educational meetings on an interactive Brief } \\
\text { Alcohol Intervention, with theory, role-play exercises, } \\
\text { checklists, and a textbook. Educational materials for } \\
\text { professionals handing out to the patient (Educational } \\
\text { meetings; educational materials) } \\
\text { Control: Professional oriented: Lipid management workshop, } \\
\text { including alcohol use }\end{array}$ & $\begin{array}{l}\text { BI: NR }(p>0.05) \\
\text { Alcohol } \\
\text { consumption: } \\
\text { NR }(p>0.05)\end{array}$ \\
\hline
\end{tabular}




\begin{tabular}{|c|c|c|c|c|c|}
\hline $\begin{array}{l}\text { Study, year } \\
\text { (ref) }\end{array}$ & $\begin{array}{l}\text { Design, study } \\
\text { duration }\end{array}$ & $\begin{array}{l}\text { Setting (country; } \\
\text { setting; type of } \\
\text { health care } \\
\text { professionals) }\end{array}$ & Participants & Implementation strategy (IS) vs Control & $\begin{array}{l}\text { Outcome type*: } \\
\text { Effect Size } \\
(95 \%-C I)^{\#}\end{array}$ \\
\hline $\begin{array}{l}\text { Friedmann et } \\
\text { al } 2006(39)\end{array}$ & $\begin{array}{l}\text { RCT, study } \\
\text { duration } 2 \text { years }\end{array}$ & $\begin{array}{l}\text { - United States } \\
\text { - Primary health } \\
\text { care practice } \\
\text { - GPs (15 } \\
\text { physicians and } 3 \\
\text { mid-level } \\
\text { clinicians) }\end{array}$ & $\begin{array}{l}\text { Physicians } \mathrm{N}=18 \\
(\text { Intervention group } \mathrm{N}= \\
12 \text {; Control group } \mathrm{N}=6 \text { ) }\end{array}$ & $\begin{array}{l}\text { IS: Three educational meetings (initial training about the care } \\
\text { model, a luncheon } 6 \text { weeks later, a booster training session } 6 \\
\text { months later. Educational materials clipped to the charts of } \\
\text { eligible patients (Educational meetings; reminders) } \\
\text { Control: Usual care }\end{array}$ & $\begin{array}{l}\text { Screening: OR } \\
2.8(1.3-5.8)) \\
\text { BI: OR }-0.15(- \\
0.26--0.06)\end{array}$ \\
\hline $\begin{array}{l}\text { Funk et al } \\
2005(40) \\
\text { (including } \\
\text { secondary } \\
\text { studies }(69- \\
71)\end{array}$ & $\begin{array}{l}\text { RCT, study } \\
\text { duration } \\
\text { unknown, } \\
\text { implementation } \\
\text { period of } 12 \\
\text { weeks }\end{array}$ & $\begin{array}{l}\text { - Australia, New } \\
\text { Zealand, } \\
\text { England, } \\
\text { Belgium, } \\
\text { Catalonia, } \\
\text { Denmark; } \\
\text { - Primary health } \\
\text { care practice; } \\
\text { - GPs }\end{array}$ & $\begin{array}{l}\text { General practitioners } \\
\mathrm{N}=727 \text { (Intervention } \\
\text { group } 1 \mathrm{~N}=255 \text {; } \\
\text { Intervention group } 2 \\
\mathrm{~N}=263 \text {; Control group } \\
\mathrm{N}=209 \text { ) }\end{array}$ & $\begin{array}{l}\text { Two IS's. } \\
\text { IS 1: Outreach training session relating to a brief intervention } \\
\text { programme (Educational outreach visits) } \\
\text { IS 2: Outreach training session relating to a brief intervention } \\
\text { programme and ongoing support and advice regarding } \\
\text { programme implementation issues through biweekly } \\
\text { telephone calls (England) and/or practice visits (Australia) } \\
\text { (Educational outreach visits) }{ }^{\mathrm{a}} \\
\text { Control: Usual care }\end{array}$ & $\begin{array}{l}\text { Screening: NR } \\
(\mathrm{p}<0.005) \\
\text { BI: NR } \\
(p<0.001) \\
\text { cost- } \\
\text { effectiveness }^{¥}\end{array}$ \\
\hline $\begin{array}{l}\text { Kaner } 2003 \\
(41)\end{array}$ & $\begin{array}{l}\text { RCT, study } \\
\text { duration } 3 \\
\text { months }\end{array}$ & $\begin{array}{l}\text { - United Kingdom; } \\
\text { - Primary health } \\
\text { care practice; } \\
\text { - Nurses }\end{array}$ & $\begin{array}{l}\text { Practices } \mathrm{N}=128 \text {. } \\
\text { (Intervention group } 1 \\
\mathrm{~N}=50 \text {; Intervention group } \\
2 \mathrm{~N}=48 \text {; Control group } \\
\mathrm{N}=30 \text { ). N participating } \\
\text { nurses unclear. }\end{array}$ & $\begin{array}{l}\text { Two IS‘s. } \\
\text { IS 1: Educational outreach visits about the programme, SBI } \\
\text { procedures and practical problems (Educational outreach } \\
\text { visits) } \\
\text { IS 2: Same educational outreach visits as above + two- } \\
\text { weekly telephone calls for support and advice (Educational } \\
\text { outreach visits) } \\
\text { Control: Professional oriented: written implementation } \\
\text { guidelines }\end{array}$ & $\begin{array}{l}\text { Screening: NR } \\
(\mathrm{p}=0.0025) \\
\text { BI: } p=0.025 \\
\text { costs; cost- } \\
\text { effectiveness }\end{array}$ \\
\hline $\begin{array}{l}\text { Lockyer et al } \\
1996(42)\end{array}$ & $\begin{array}{l}\text { RCT, study } \\
\text { duration assumed } \\
\text { to be } 4 \text { months }\end{array}$ & $\begin{array}{l}\text { - Canada; } \\
\text { - Primary health } \\
\text { care practice; } \\
\text { - Family } \\
\text { physicians and }\end{array}$ & $\begin{array}{l}\text { Family physicians and } \\
\text { general practitioners } \\
\mathrm{N}=54 \text { (Intervention group } \\
\mathrm{N}=26 \text {; Control group } \\
\mathrm{N}=28 \text { ) }\end{array}$ & $\begin{array}{l}2 \text { intervention groups. Group 1: family physicians; Group } 2 \text { : } \\
\text { general practitioners. } \\
\text { IS: Educational program: one day education including visits } \\
\text { to five local treatment facilities and their therapeutic } \\
\text { programs; and three evening sessions (Educational meetings; } \\
\text { educational outreach visits) }\end{array}$ & $\begin{array}{l}\text { Screening: F } \\
{[2,49]=4,82} \\
(p<0.033) \\
\text { BI: F } \\
{[2,49]=16,69} \\
(p<0.001)\end{array}$ \\
\hline
\end{tabular}




\begin{tabular}{|c|c|c|c|c|c|}
\hline $\begin{array}{l}\text { Study, year } \\
\text { (ref) }\end{array}$ & $\begin{array}{l}\text { Design, study } \\
\text { duration }\end{array}$ & $\begin{array}{l}\text { Setting (country; } \\
\text { setting; type of } \\
\text { health care } \\
\text { professionals) }\end{array}$ & Participants & Implementation strategy (IS) vs Control & $\begin{array}{l}\text { Outcome type*: } \\
\text { Effect Size } \\
(95 \%-C I)^{\#}\end{array}$ \\
\hline & & $\begin{array}{l}\text { general } \\
\text { practitioners }\end{array}$ & & Control: Assumed to be usual care. & \\
\hline $\begin{array}{l}\text { Rose et al } \\
2008(25)\end{array}$ & $\begin{array}{l}\text { RCT, study } \\
\text { duration } 2 \text { years }\end{array}$ & $\begin{array}{l}\text { - United States; } \\
\text { - Primary health } \\
\text { care practice; } \\
\text { - Assumed to be } \\
\text { GPs }\end{array}$ & $\begin{array}{l}22 \text { practice units } \\
\text { (Intervention group } \mathrm{N}=11 \text {; } \\
\text { Control group } \mathrm{N}=11 \text { ). } \mathrm{N} \\
\text { individual professionals } \\
\text { not clear }\end{array}$ & $\begin{array}{l}\text { IS: Written materials, on site academic detailing, } \\
\text { performance feedback through practice reports, network } \\
\text { meetings (Distribution of educational materials; educational } \\
\text { outreach visits; audit and feedback; educational meetings) } \\
\text { Control: Professional oriented: written materials. }\end{array}$ & $\begin{array}{l}\text { Screening: OR } \\
8.1(1.7-38.2) \\
\text { BI: OR 5.5 }(1.3- \\
\text { 23.3) }\end{array}$ \\
\hline $\begin{array}{l}\text { Saitz et al } \\
2003(43)\end{array}$ & $\begin{array}{l}\mathrm{RCT} \text {, study } \\
\text { duration } 1,5 \text { years }\end{array}$ & $\begin{array}{l}\text { - United States; } \\
\text { - Primary health } \\
\text { care practice; } \\
\text { - GPs }\end{array}$ & $\begin{array}{l}\text { Faculty and resident } \\
\text { primary health care } \\
\text { physicians } \mathrm{N}=41 \\
\text { (Intervention group } \mathrm{N}=20 \text {; } \\
\text { Control group } \mathrm{N}=21 \text { ) } \\
\text { Patients } \mathrm{N}=312 \\
\text { (Intervention group } \\
\mathrm{N}=168 \text {; Control group } \\
\mathrm{N}=144 \text { ) }\end{array}$ & $\begin{array}{l}\text { IS: Feedback patients' alcohol screening results to physicians } \\
\text { with recommendations (Patient mediated interventions) }{ }^{\mathrm{a}} \\
\underline{\text { Control: Usual care }}\end{array}$ & $\begin{array}{l}\text { BI: NR } \\
\text { Alcohol } \\
\text { consumption: } \\
\text { NR }\end{array}$ \\
\hline $\begin{array}{l}\text { Williams et al } \\
2010(44)\end{array}$ & $\begin{array}{l}\text { RCT, study } \\
\text { duration } 3 \text { years }\end{array}$ & $\begin{array}{l}\text { - United States; } \\
\text { - Outpatient clinic; } \\
\text { - Physicians, } \\
\text { residents, nurse } \\
\text { practitioners } \\
\text { physician } \\
\text { assistants }\end{array}$ & $\begin{array}{l}\text { Physicians, residents, } \\
\text { nurse practitioners, and } \\
\text { physician assistants }(\mathrm{N}= \\
\text { not clear) } \\
\text { Patients } \mathrm{N}=1,358 \\
\text { (Intervention group } \\
\mathrm{N}=692 \text {; Control group } \\
\mathrm{N}=666 \text { ) }\end{array}$ & $\begin{array}{l}\text { IS: Reminder for primary health care provider after patients' } \\
\text { positive alcohol screen; e-mail alerts to professionals } \\
\text { (Reminders) }^{\mathrm{a}} \\
\underline{\text { Control: Assumed to be usual care }}\end{array}$ & $\begin{array}{l}\text { Alcohol } \\
\text { consumption: } \\
\text { NR (p0.25) }\end{array}$ \\
\hline \multicolumn{6}{|c|}{ Organisational oriented implementation strategies } \\
\hline $\begin{array}{l}\text { Brown et al } \\
2007 \text { (47) }\end{array}$ & $\begin{array}{l}\text { RCT, study } \\
\text { duration } 12 \\
\text { months }\end{array}$ & $\begin{array}{l}\text { - United States; } \\
\text { - Primary health } \\
\text { care practice; }\end{array}$ & $\begin{array}{l}\text { Patients } N=897 \text {. Sub set } \\
\text { of } n=472 \text { patients with } \\
\text { alcohol abuse } \\
\text { (Intervention group }\end{array}$ & $\begin{array}{l}\text { IS: Delivery of counseling via telephone and mail (Changes } \\
\text { to the setting/ service delivery) } \\
\text { Control : Usual care }\end{array}$ & $\begin{array}{l}\text { Alcohol } \\
\text { consumption: } \\
\text { NR }(p>0.05)\end{array}$ \\
\hline
\end{tabular}




\begin{tabular}{|c|c|c|c|c|c|}
\hline $\begin{array}{l}\text { Study, year } \\
\text { (ref) }\end{array}$ & $\begin{array}{l}\text { Design, study } \\
\text { duration }\end{array}$ & $\begin{array}{l}\text { Setting (country; } \\
\text { setting; type of } \\
\text { health care } \\
\text { professionals) }\end{array}$ & Participants & Implementation strategy (IS) vs Control & $\begin{array}{l}\text { Outcome type*: } \\
\text { Effect Size } \\
(95 \%-C I)^{\#}\end{array}$ \\
\hline & & $\begin{array}{l}\text { Type of health } \\
\text { care professionals } \\
\text { not reported }\end{array}$ & $\begin{array}{l}\mathrm{n}=231 ; \text { Control group: } \\
\mathrm{n}=241)\end{array}$ & & \\
\hline $\begin{array}{l}\text { Vinson et al } \\
2000(45)\end{array}$ & $\begin{array}{l}\text { RCT, study } \\
\text { duration } 12 \\
\text { months }\end{array}$ & $\begin{array}{l}\text { - United States; } \\
\text { - Primary health } \\
\text { care practice; } \\
\text { - GPs }\end{array}$ & $\begin{array}{l}\text { Patients } \mathrm{N}=80(\mathrm{~N} \\
\text { participants per group not } \\
\text { reported) }\end{array}$ & $\begin{array}{l}\text { IS: Computer-Generated Written Behavioural Contracts. } \\
\text { Physician reviewed the contract briefly with the patient, } \\
\text { signed it, and encourage compliance with its terms (Changes } \\
\text { in scope and nature of benefits and services) } \\
\text { Control: Usual care }\end{array}$ & $\begin{array}{l}\text { Alcohol } \\
\text { consumption: } \\
0.34(\mathrm{p}>0.05)\end{array}$ \\
\hline $\begin{array}{l}\text { Wilson et al } \\
1992(46)\end{array}$ & $\begin{array}{l}\text { CCT, study } \\
\text { duration not clear }\end{array}$ & $\begin{array}{l}\text { - United Kingdom; } \\
\text { - Primary health } \\
\text { care practice; } \\
\text { - GPs }\end{array}$ & $\begin{array}{l}\text { Physicians } \mathrm{N}=16 \text {. } \\
\text { Allocation at the level of } \\
\text { days/sessions ( } \mathrm{N} \text { sessions } \\
\text { Intervention group } \\
\mathrm{N}=1,411 \text {; Control group } 1 \\
\mathrm{~N}=1,478 \text {; Control group } 2 \\
\mathrm{~N}=1,432 \text { ) }\end{array}$ & $\begin{array}{l}\text { IS: Expanding consultation time from on average } 7.5 \\
\text { minutes to } 10 \text { minutes per patient. } \\
\text { Control group 1: matched for time of day and day of the } \\
\text { week, drawn from the period before the trial (Changes in } \\
\text { scope and nature of benefits and services) Control group 2: } \\
\text { matched for time of day and day of the week, during the trial } \\
\text { phase, in the alternate weeks when an experimental session } \\
\text { was not scheduled (Changes in scope and nature of benefits } \\
\text { and services) })^{\mathrm{a}}\end{array}$ & $\begin{array}{l}\text { Screening: } 1-\mathrm{NR} \\
(\mathrm{p}<0.05) 2-\mathrm{NR} \\
(\mathrm{p}>0.05) \\
\mathrm{BI}: 1: \mathrm{NR} \\
(\mathrm{p}<0.001) 2: \mathrm{NR} \\
(\mathrm{p}<0.01)\end{array}$ \\
\hline \multicolumn{6}{|c|}{ Patient oriented implementation strategies } \\
\hline $\begin{array}{l}\text { Wang et al } \\
2010(48)\end{array}$ & $\begin{array}{l}\text { RCT, study } \\
\text { duration } 1 \text { month }\end{array}$ & $\begin{array}{l}\text { - United States; } \\
\text { - Emergency } \\
\text { department } \\
\text { setting }\end{array}$ & $\begin{array}{l}\text { Patients } \mathrm{N}=252 \\
\text { (Intervention group } \mathrm{N}=95 \text {; } \\
\text { Control group } \mathrm{N}=93 \text { ) }\end{array}$ & $\begin{array}{l}\text { IS: Subjects in the intervention group were given a brochure } \\
\text { titled, "Alcohol, How Much is Too Much?" (Printed } \\
\text { educational materials for patients) } \\
\text { Control: Assumed to be usual care }\end{array}$ & $\begin{array}{l}\text { Alcohol } \\
\text { consumption: } \\
\mathrm{NR}(\mathrm{p}=0.95)\end{array}$ \\
\hline \multicolumn{6}{|c|}{ Professional and organisational oriented implementation strategies } \\
\hline $\begin{array}{l}\text { Adams et al } \\
1998(49)\end{array}$ & $\begin{array}{l}\text { RCT, study } \\
\text { duration } 32 \\
\text { months }\end{array}$ & $\begin{array}{l}\text { - Assumed to be in } \\
\text { United States; } \\
\text { - Primary health } \\
\text { care practice; }\end{array}$ & $\begin{array}{l}\text { Physicians } \mathrm{N}=21 \\
\text { Resident } \mathrm{N}=1 \text { resident; } \\
\text { Nurse practitioners } \mathrm{N}=7 \\
\text { Patients } \mathrm{N}=344 \\
\text { (Intervention group }\end{array}$ & $\begin{array}{l}\text { IS: Educational meetings: Training in motivational } \\
\text { interviewing and topics about alcohol }(2,5 \text { hours). }+ \\
\text { intervention algorithm (Educational meetings; changes in } \\
\text { medical record system) })^{\mathrm{b}} \\
\text { Control: Usual care }\end{array}$ & $\begin{array}{l}\text { Screening: NR } \\
(\mathrm{p}<0.001) \\
\text { BI: NR } \\
(\mathrm{p}<0.001)\end{array}$ \\
\hline
\end{tabular}




\begin{tabular}{|c|c|c|c|c|c|}
\hline $\begin{array}{l}\text { Study, year } \\
\text { (ref) }\end{array}$ & $\begin{array}{l}\text { Design, study } \\
\text { duration }\end{array}$ & $\begin{array}{l}\text { Setting (country; } \\
\text { setting; type of } \\
\text { health care } \\
\text { professionals) }\end{array}$ & Participants & Implementation strategy (IS) vs Control & $\begin{array}{l}\text { Outcome type*: } \\
\text { Effect Size } \\
(95 \%-C I)^{\#}\end{array}$ \\
\hline & & $\begin{array}{l}\text { - Physicians, } \\
\text { nurses }\end{array}$ & $\begin{array}{l}N=200 \text {; Control group } \\
N=144 \text { ) }\end{array}$ & & \\
\hline $\begin{array}{l}\text { Ferrer } 2009 \\
(50)\end{array}$ & $\begin{array}{l}\text { RCT, study } \\
\text { duration median } \\
\text { time = } 360 \text { days } \\
\text { (range } 159-565 ; \\
\text { 10th percentile } \\
\text { 215; 90th } \\
\text { percentile } 441 \text { ) }\end{array}$ & $\begin{array}{l}\text { - United States; } \\
\text { - Primary health } \\
\text { care practice; } \\
\text { - GPs and medical } \\
\text { assistants }\end{array}$ & $\begin{array}{l}\text { GPs (N unclear); Medical } \\
\text { Assistants }(\mathrm{N}=100) ; \\
\text { Patients } \mathrm{N}=864 \\
\text { (Intervention group } \\
\mathrm{N}=437 \text { of which } \mathrm{N}=57 \\
\text { drinking; Control group } \\
\mathrm{N}=427 \text { of which } \mathrm{N}=67 \\
\text { drinking) }\end{array}$ & $\begin{array}{l}\text { IS: Professional role revision: assessments and referrals were } \\
\text { performed by medical assistants; Educational meetings: three } \\
\text { training sessions about how to assess, inform, encourage and } \\
\text { refer patients (Educational meetings; Skill mix changes) }{ }^{\mathrm{b}} \\
\text { Control: Usual care }\end{array}$ & $\begin{array}{l}\text { BI: NA } \\
\text { alcohol } \\
\text { consumption: } \\
\text { NR ( }>>0.05)\end{array}$ \\
\hline $\begin{array}{l}\text { Oslin et al } \\
2003(52)\end{array}$ & $\begin{array}{l}\text { RCT, study } \\
\text { duration } 24 \\
\text { weeks }\end{array}$ & $\begin{array}{l}\text { - United States; } \\
\text { - General practice/ } \\
\text { primary health } \\
\text { care clinic/ } \\
\text { family practice } \\
\text { - Clinicians }\end{array}$ & $\begin{array}{l}\text { Clinicians from different } \\
\text { primary health care } \\
\text { settings } N=37 \text {; patients } \\
\mathrm{N}=97 \text { (Intervention group; } \\
\mathrm{N}=46 \text { control group } \\
\mathrm{N}=51 \text { ) }\end{array}$ & $\begin{array}{l}\text { IS: Patient Telephone disease management by a behavioural } \\
\text { health specialist + educating professionals (Skill mix } \\
\text { changes; educational meetings) } \\
\text { Control: Usual care }\end{array}$ & $\begin{array}{l}\text { Alcohol } \\
\text { consumption: } \\
\mathrm{OR}=0.28 \\
(\mathrm{p}=0.142)\end{array}$ \\
\hline $\begin{array}{l}\text { Oslin et al } \\
2006(51)\end{array}$ & $\begin{array}{l}\text { RCT, study } \\
\text { duration } 9 \\
\text { months }\end{array}$ & $\begin{array}{l}\text { - United States; } \\
\text { - Primary health } \\
\text { care practice; and } \\
\text { Community } \\
\text { based care/ } \\
\text { community health } \\
\text { centres }\end{array}$ & $\begin{array}{l}\text { Patients } \mathrm{N}=560 \\
\text { (Intervention group } 1 \mathrm{~N}= \\
227 ; \text { Intervention group } 2 \\
\mathrm{~N}=239 ; \text { no control group) }\end{array}$ & $\begin{array}{l}\text { Two IS‘s, no control group. } \\
\text { IS1. Integrated care model: participants receive mental health } \\
\text { or substance abuse services in the primary health care clinic } \\
\text { from a mental health or substance abuse provider + } \\
\text { education (Educational meetings) } \\
\text { IS2. Enhanced specialty referral model includes referral from } \\
\text { primary health care and provides mental health or substance } \\
\text { abuse services in a specialty mental health or substance } \\
\text { abuse clinic (Educational meetings; formal integration of } \\
\text { services) }^{\mathrm{b}}\end{array}$ & $\begin{array}{l}\text { Alcohol } \\
\text { consumption: } \\
\text { MD -0.1 (-2.5- } \\
2.2 ; \mathrm{p}=0.913)\end{array}$ \\
\hline $\begin{array}{l}\text { Reiff- } \\
\text { Hekking } 2005 \\
\text { (53) } \\
\text { (including }\end{array}$ & $\begin{array}{l}\text { RCT, study } \\
\text { duration } 3 \text { years }\end{array}$ & $\begin{array}{l}\text { - United States; } \\
\text { - Ambulatory } \\
\text { primary health } \\
\text { care setting; }\end{array}$ & $\begin{array}{l}\text { Physicians } \mathrm{N}=38 ; \text { Nurses } \\
\mathrm{N}=8 \text {; Patients } \mathrm{N}=530 \\
\text { (Intervention group } \\
\mathrm{N}=248 \text {; Control group } \\
\mathrm{N}=233 \text { ) }\end{array}$ & $\begin{array}{l}\text { IS: Training; Individual tutorial (including education } \\
\text { materials); role-play; office support system (lifestyle } \\
\text { interview summary sheet; intervention algorithm) } \\
\text { (Educational meetings; educational materials; changes in } \\
\text { medical record system) }\end{array}$ & $\begin{array}{l}\text { Alcohol } \\
\text { consumption: } \\
\text { NR }(p=0.03)\end{array}$ \\
\hline
\end{tabular}




\begin{tabular}{|c|c|c|c|c|c|}
\hline $\begin{array}{l}\text { Study, year } \\
\text { (ref) }\end{array}$ & $\begin{array}{l}\text { Design, study } \\
\text { duration }\end{array}$ & $\begin{array}{l}\text { Setting (country; } \\
\text { setting; type of } \\
\text { health care } \\
\text { professionals) }\end{array}$ & Participants & Implementation strategy (IS) vs Control & $\begin{array}{l}\text { Outcome type*: } \\
\text { Effect Size } \\
(95 \%-C I)^{\#}\end{array}$ \\
\hline $\begin{array}{l}\text { secondary } \\
\text { study }(72))\end{array}$ & & $\begin{array}{l}\text { - Physicians; } \\
\text { nurses }\end{array}$ & & $\begin{array}{l}\text { Control: Professional oriented: Encouraged to identify and } \\
\text { intervene with patients with alcohol related issues; } \\
\text { Encouraged to attend weekly conference series }\end{array}$ & \\
\hline $\begin{array}{l}\text { Rodney et al } \\
1985(54)\end{array}$ & $\begin{array}{l}\text { CCT, study } \\
\text { duration } 5 \text { years }\end{array}$ & $\begin{array}{l}\text { - United States; } \\
\text { - Primary health } \\
\text { care practice; } \\
\text { - Physicians, } \\
\text { Nurses, } \\
\text { Psychologist, } \\
\text { social worker, } \\
\text { dietician }\end{array}$ & $\begin{array}{l}\text { Physicians } \mathrm{N}=\text { assumed to } \\
\text { be } 22 \text { residents (medicine) } \\
\text { and } 32 \text { family physicians; } \\
\text { Nurses } \mathrm{N}=2 \text {; Psychologist } \\
\mathrm{N}=1 \text {; licensed clinical } \\
\text { social worker } \mathrm{N}=1 \text {; } \\
\text { dietician } \mathrm{N}=1 \text {; Patients } \\
\mathrm{N}=390 \text { (Intervention } \\
\text { group } \mathrm{N}=114 \text {; Control } \\
\text { group } \mathrm{N}=110 \text { ) }\end{array}$ & $\begin{array}{l}\text { IS: Education, educational materials + reminders (face sheet } \\
\text { on record) (Educational meetings; educational materials; } \\
\text { reminders; changes in medical record systems) } \\
\text { Control: Professional and organisational oriented: year 1-3: } \\
\text { similar intervention group. Year 4-5: chart review sessions in } \\
\text { which residents reviewed three to five of their records during } \\
\text { July, November and April }\end{array}$ & $\begin{array}{l}\text { Screening: NR } \\
(p>0.05)\end{array}$ \\
\hline \multicolumn{6}{|c|}{ Professional and patient oriented Implementation strategies } \\
\hline $\begin{array}{l}\text { Drevenhorn } \\
2012(23) \\
\text { (secondary } \\
\text { study } \\
\text { included (73)) }\end{array}$ & $\begin{array}{l}\text { RCT, study } \\
\text { duration } 2 \text { years }\end{array}$ & $\begin{array}{l}\text { - Sweden; } \\
\text { - ? } \\
\text { - Nurses }\end{array}$ & $\begin{array}{l}\text { Nurses } \mathrm{N}=33 \\
\text { (intervention group } \mathrm{N}=19 ; \\
\text { Control group } \mathrm{N}=14 \text { ). } \\
\text { Patients } \mathrm{N}=213 \\
\text { (Intervention group } \\
\mathrm{N}=153 \text {; Control group } \\
\mathrm{N}=60 \text { ) }\end{array}$ & $\begin{array}{l}\text { IS: educational outreach visits, with education in stages of } \\
\text { change, Motivational Interviewing and applying guidelines } \\
\text { for cardiovascular prevention, lifestyle factors and } \\
\text { pharmacological treatment. Distribution of educational } \\
\text { materials for nurses. Educational materials for patient to } \\
\text { support patients' self-management (Educational outreach } \\
\text { visits; Distribution of educational materials; Patient self- } \\
\text { management education materials) })^{\mathrm{b}} \\
\text { Control: Usual care }\end{array}$ & $\begin{array}{l}\text { BI: NR } \\
\text { Alcohol } \\
\text { consumption: } \\
\text { NR }\end{array}$ \\
\hline $\begin{array}{l}\text { Fink et al } \\
2005(57)\end{array}$ & $\begin{array}{l}\text { RCT, study } \\
\text { duration } 2,5 \text { years }\end{array}$ & $\begin{array}{l}\text { - United States; } \\
\text { - Primary health } \\
\text { care practice; } \\
\text { - Physicians }\end{array}$ & $\begin{array}{l}\text { Physicians }(\mathrm{N}=\text { not clear) } \\
\text { and patients } \mathrm{N}=665 \\
\text { (Intervention group } 1 \mathrm{~N}= \\
245 ; \text { Intervention group } 2 \\
\mathrm{~N}=198 \text {; Control group } \\
\mathrm{N}=222 \text { ) }\end{array}$ & 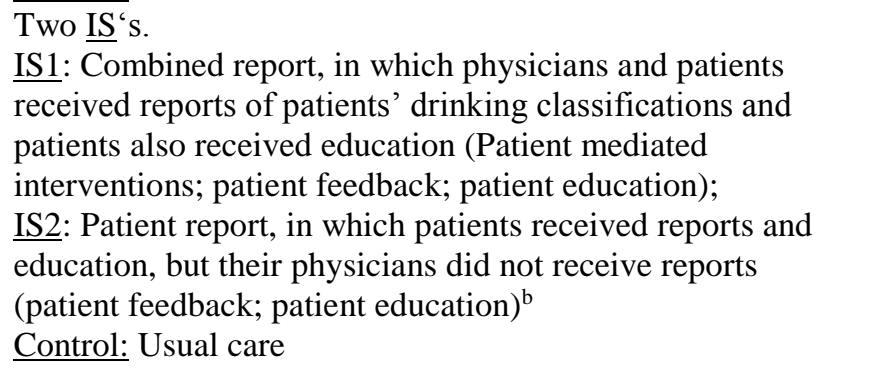 & $\begin{array}{l}\text { Alcohol } \\
\text { consumption: } \\
\text { NR }(1: \mathrm{p}<0.05 \\
2: \mathrm{p}>0.05)\end{array}$ \\
\hline
\end{tabular}




\begin{tabular}{|c|c|c|c|c|c|}
\hline $\begin{array}{l}\text { Study, year } \\
\text { (ref) }\end{array}$ & $\begin{array}{l}\text { Design, study } \\
\text { duration }\end{array}$ & $\begin{array}{l}\text { Setting (country; } \\
\text { setting; type of } \\
\text { health care } \\
\text { professionals) }\end{array}$ & Participants & Implementation strategy (IS) vs Control & $\begin{array}{l}\text { Outcome type*: } \\
\text { Effect Size } \\
(95 \%-C I)^{\#}\end{array}$ \\
\hline \multicolumn{6}{|c|}{ Organisational and patient oriented implementation strategies } \\
\hline $\begin{array}{l}\text { Kypri et al } \\
2004 \text { (59) }\end{array}$ & $\begin{array}{l}\text { RCT, study } \\
\text { duration } 6 \\
\text { months }\end{array}$ & $\begin{array}{l}\text { - New Zealand; } \\
\text { - Community } \\
\text { based care/ } \\
\text { community health } \\
\text { centres }\end{array}$ & $\begin{array}{l}\text { Patients } \mathrm{N}=104 \\
\text { (Intervention } \mathrm{N}=42 ; \\
\text { Control } \mathrm{N}=41 \text { ) }\end{array}$ & $\begin{array}{l}\text { IS: Web-based screening and brief intervention including } \\
\text { patient feedback (changes to the setting/ site of service } \\
\text { delivery; patient feedback) } \\
\text { Control: Organisational oriented: 'Alcohol Facts and Effects' } \\
\text { leaflet was given by the research assistant }\end{array}$ & $\begin{array}{l}\text { Alcohol } \\
\text { consumption: } \\
\text { Ratio of } \\
\text { geometric means } \\
0.80(0.63- \\
1.02 ; \mathrm{p} 0.08)\end{array}$ \\
\hline $\begin{array}{l}\text { Kypri et al } \\
2005(58)\end{array}$ & $\begin{array}{l}\mathrm{RCT} \text {, study } \\
\text { duration } 6 \text { weeks }\end{array}$ & $\begin{array}{l}\text { - New Zealand; } \\
\text { - General practice/ } \\
\text { primary health } \\
\text { care clinic/ } \\
\text { family practice }\end{array}$ & $\begin{array}{l}\text { Patients } \mathrm{N}=218 \\
\text { (Intervention Group 1: } \\
\mathrm{N}=72 \text {; Intervention Group } \\
2 \mathrm{~N}=74 \text {; Control: } \mathrm{N}=72 \text { ) }\end{array}$ & $\begin{array}{l}\text { Two IS's. } \\
\text { IS1. Computerised assessment }+ \text { feedback and advice on } \\
\text { patients' fruit and vegetable consumption, physical activity, } \\
\text { alcohol consumption, and smoking (changes to the setting/ } \\
\text { site of service delivery; patient feedback) } \\
\text { IS2. Computerised assessment only } \\
\text { Control: Untargeted activity: Minimal contact at baseline }\end{array}$ & $\begin{array}{l}\text { Alcohol } \\
\text { consumption: } F \\
=0.208 \\
(\mathrm{p}=0.813)\end{array}$ \\
\hline $\begin{array}{l}\text { Kypri et al } \\
2008(24)\end{array}$ & $\begin{array}{l}\text { RCT, study } \\
\text { duration } 12 \\
\text { months }\end{array}$ & $\begin{array}{l}\text { - New Zealand; } \\
\text { - General practice/ } \\
\text { primary health } \\
\text { care clinic/ } \\
\text { family practice }\end{array}$ & $\begin{array}{l}\text { Patients } \mathrm{N}=429 \\
\text { (Intervention Group 1: } \\
\mathrm{N}=138 ; \text { Intervention } \\
\text { Group 2: } \mathrm{N}=145 \text {; Control: } \\
\mathrm{N}=146 \text { ) }\end{array}$ & $\begin{array}{l}\text { Two IS`s. } \\
\text { IS1. Web-based motivational intervention (changes to the } \\
\text { setting/ site of service delivery) } \\
\text { IS2. Web-based motivational intervention with further } \\
\text { interventions } 1 \text { and } 6 \text { months later (including personalised } \\
\text { feedback) (changes to the setting/ site of service delivery; } \\
\text { patient feedback) } \\
\text { Control: Patient oriented: Information pamphlet on health } \\
\text { effects of alcohol consumption }\end{array}$ & $\begin{array}{l}\text { Alcohol } \\
\text { consumption: } \\
1(6 \text { months): Rate } \\
\text { ratio } 0.79 \text { ( } 0.68 \\
\text { to } 0.94), \\
2(6 \text { months): Rate } \\
\text { ratio } 0.85(0.73 \\
\text { to } 1.00), 1(12 \\
\text { months): Rate } \\
\text { ratio } 0.86(0.74 \\
\text { to } 1.01), \\
2(12 \text { months }): \\
\text { Rate ratio } 0.92 \\
\text { ( } 0.79 \text { to } 1.07)\end{array}$ \\
\hline \multicolumn{6}{|c|}{ Professional, organisational and patient oriented implementation strategies } \\
\hline $\begin{array}{l}\text { Beurden van } \\
2012(11) \\
\text { (secondary } \\
\text { study } \\
\text { included (74)) }\end{array}$ & $\begin{array}{l}\text { RCT, study } \\
\text { duration } 2 \text { years }\end{array}$ & $\begin{array}{l}\text { - Netherlands; } \\
\text { - Primary health } \\
\text { care practice; } \\
\text { - GPs }\end{array}$ & $\begin{array}{l}\text { General practitioners } \\
\mathrm{N}=119 \text { (Intervention } \\
\text { group } \mathrm{N}=47 \text {; Control } \\
\text { group } \mathrm{N}=47 \text { ); }\end{array}$ & $\begin{array}{l}\text { IS: Distribution of the guideline; a reminder-card to display } \\
\text { on the GPs desk; educational training session tailored to } \\
\text { professionals' attitudes; feedback report on patient alcohol } \\
\text { consumption risk level; facilitation of the cooperation with } \\
\text { local addiction services for support and referral; outreach }\end{array}$ & $\begin{array}{l}\text { Screening:NR } \\
(\mathrm{p}=0.60) \\
\text { BI: } \mathrm{NR}(\mathrm{p}=0.57) \\
\text { Alcohol } \\
\text { consumption: }\end{array}$ \\
\hline
\end{tabular}




\begin{tabular}{|c|c|c|c|c|c|}
\hline $\begin{array}{l}\text { Study, year } \\
\text { (ref) }\end{array}$ & $\begin{array}{l}\text { Design, study } \\
\text { duration }\end{array}$ & $\begin{array}{l}\text { Setting (country; } \\
\text { setting; type of } \\
\text { health care } \\
\text { professionals) }\end{array}$ & Participants & Implementation strategy (IS) vs Control & $\begin{array}{l}\text { Outcome type*: } \\
\text { Effect Size } \\
(95 \%-C I)^{\#} ;\end{array}$ \\
\hline $\begin{array}{l}\text { Butler et al } \\
2003(56)\end{array}$ & $\begin{array}{l}\text { CCT, study } \\
\text { duration not clear }\end{array}$ & $\begin{array}{l}\text { - United States; } \\
\text { - Primary health } \\
\text { care practice; } \\
\text { - Physicians, nurse } \\
\text { practitioners, } \\
\text { nurses, practice } \\
\text { assistants }\end{array}$ & $\begin{array}{l}\text { Physicians } \mathrm{N}=33 \text {; Nurse } \\
\text { practitioners } \mathrm{N}=7 \text {; Nurses } \\
\mathrm{N}=5 \text {; Practice assistants } \\
\mathrm{N}=3 \text { (Intervention group } \\
\text { professionals } \mathrm{N}=62 ; \\
\text { Control group } \\
\text { professionals } \mathrm{N}=66) ; \\
\text { Patients }(\mathrm{N}=2053 \text { ) }\end{array}$ & $\begin{array}{l}\text { visits by a trained facilitator tailored to needs of practice; } \\
\text { patient information letters, leaflets and self-help booklets } \\
\text { about alcohol offered to general practices to be distributed to } \\
\text { patients; poster in the waiting room; personal feedback to the } \\
\text { patient based on their alcohol consumption risk category } \\
\text { (Distribution of educational materials; educational meetings; } \\
\text { reminders; audit and feedback; formal integration of } \\
\text { services; educational outreach visits; patient feedback) } \\
\text { Control: Guidelines were mailed to GPs; information letters } \\
\text { about problematic alcohol consumption were sent to patients. } \\
\text { Patients also received personal feedback on alcohol } \\
\text { consumption after closure of the intervention period. } \\
\text { IS: Computerised health assessment, and training how to use } \\
\text { this, and tailored feedback to patients (Educational outreach } \\
\text { visits; changes to the setting/ service delivery; patient } \\
\text { feedback) } \\
\text { Control: Usual care }\end{array}$ & $\begin{array}{l}\mathrm{NR}(\mathrm{p}=0.01 \text { in } \\
\text { opposite } \\
\text { direction) }\end{array}$ \\
\hline \multicolumn{6}{|c|}{ Organisational, patient and financial oriented implementation strategies } \\
\hline $\begin{array}{l}\text { Helzer et al } \\
2008(55)\end{array}$ & $\begin{array}{l}\text { RCT, study } \\
\text { duration } 6 \\
\text { months }\end{array}$ & $\begin{array}{l}\text { - United States; } \\
\text { - Primary health } \\
\text { care practice; } \\
\text { - Type of } \\
\text { healthcare } \\
\text { professionals not } \\
\text { reported }\end{array}$ & $\begin{array}{l}\text { care professionals } \\
\text { (profession not reported) } \\
\mathrm{N}=112 \text { (Intervention } \\
\text { group } 1 \mathrm{~N}=75 ; \\
\text { Intervention group } 2 \\
\mathrm{~N}=75 ; \text { Intervention group } \\
3 \mathrm{~N}=53 \text {; Control } \mathrm{N}=81 \text { ); } \\
\text { Patients } \mathrm{N}=338\end{array}$ & $\begin{array}{l}\text { Three IS's. } \\
\text { IS1: Daily phone calls for } 6 \text { months to an automated } \\
\text { Interactive voice response system to report alcohol } \\
\text { consumption (Changes to the setting/ service delivery) } \\
\text { IS2: As group } 1+\text { monthly patient feedback (Changes to the } \\
\text { setting/ service delivery; patient feedback) } \\
\text { IS3: As group } 2+\text { financial compensation based on } \\
\text { frequency of participants' daily calls (Changes to the setting/ } \\
\text { service delivery; provider incentives; patient feedback) } \\
\text { Control: Usual care }\end{array}$ & $\begin{array}{l}\text { Alcohol } \\
\text { consumption: } \\
\text { NR }\end{array}$ \\
\hline
\end{tabular}


Table 3 Reported cost outcomes

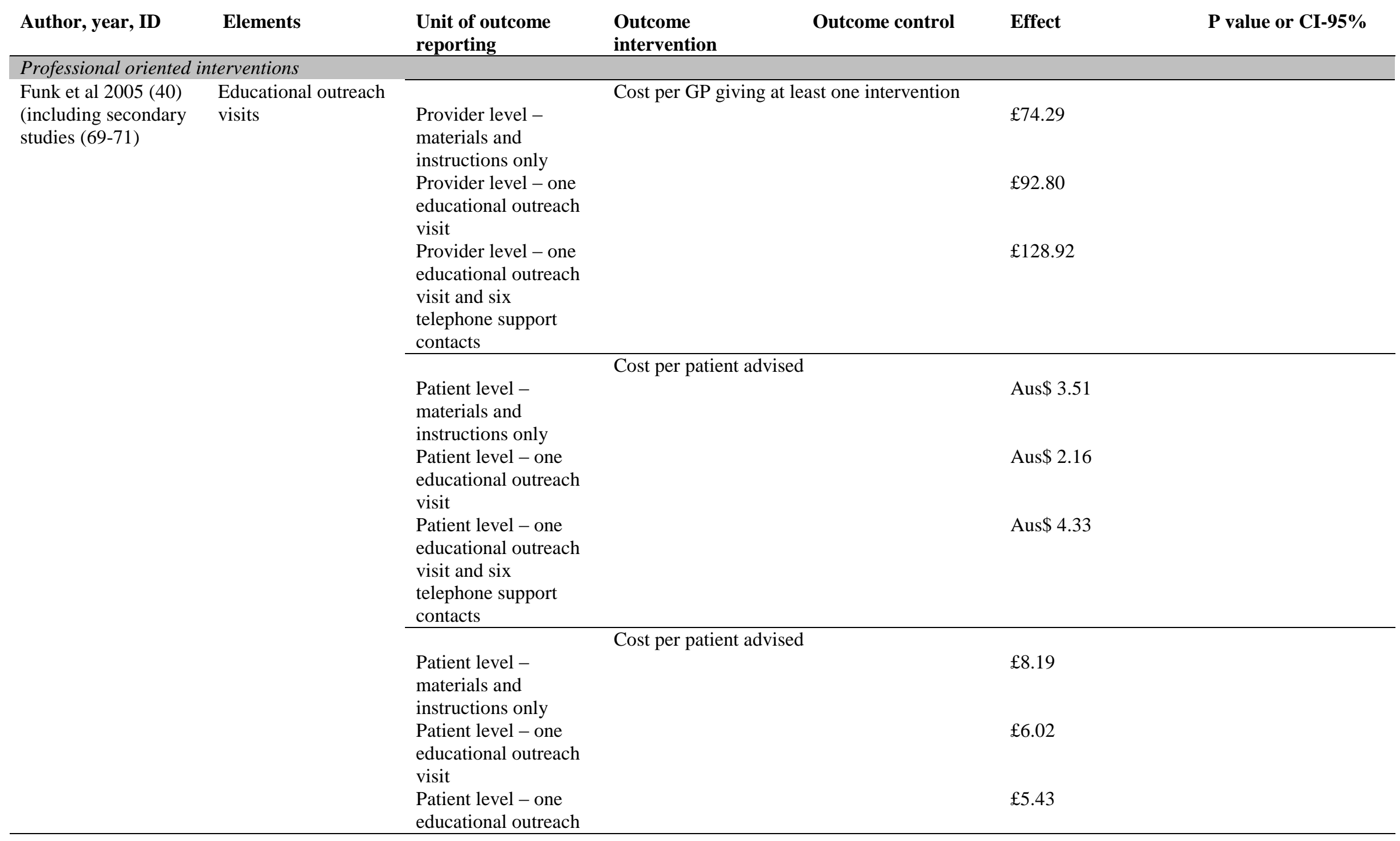




\begin{tabular}{|c|c|c|c|c|c|c|}
\hline Author, year, ID & Elements & $\begin{array}{l}\text { Unit of outcome } \\
\text { reporting }\end{array}$ & $\begin{array}{l}\text { Outcome } \\
\text { intervention }\end{array}$ & Outcome control & Effect & P value or CI-95\% \\
\hline & & $\begin{array}{l}\text { visit and six } \\
\text { telephone support } \\
\text { contacts }\end{array}$ & & & & \\
\hline Kaner 2003 (41) & $\begin{array}{l}\text { Educational outreach } \\
\text { visits }\end{array}$ & $\begin{array}{l}\text { Median number of } \\
\text { patients screened }\end{array}$ & $\begin{array}{l}\text { Full cost for trained } \\
\text { practice: } £ 157 \\
\text { Full cost for trained } \\
\text { and supported } \\
\text { practice } £ 163\end{array}$ & $\begin{array}{l}\text { Full cost of } \\
\text { promoting and } \\
\text { implementing SBI } \\
£ 93 \text { per practice }\end{array}$ & $\begin{array}{l}\text { When full costs of } \\
\text { GP-led SBI were } \\
\text { considered, nurses } \\
\text { were more cost- } \\
\text { effective at delivering } \\
\text { brief interventions. } \\
\text { However, if just } \\
\text { promotional costs } \\
\text { were considered, } \\
\text { GPs' were more cost- } \\
\text { effective. }\end{array}$ & $\mathrm{p}<.001$ \\
\hline
\end{tabular}


Table 4. Meta-regression analysis: predictor variable effects on alcohol consumption based on 21 outcomes from 14 studies

\begin{tabular}{lllll} 
Comparison & $\boldsymbol{\beta}$ & $\mathbf{9 5 \%}$-CI & $\boldsymbol{p}$ \\
\hline 1. & Single implementation strategy & -0.022 & & \\
& Multiple implementation strategy & 0.108 & $-0.068-0.284$ & 0.206 \\
\hline 2.* & Organisational oriented & 0.202 & $-0.014-0.417$ & 0.063 \\
& Patient oriented & 0.071 & $-0.193-0.336$ & 0.543 \\
& Professional+organisational oriented & 0.258 & $0.116-0.400$ & 0.004 \\
& Professional+patient oriented & 0.258 & $0.091-0.426$ & 0.008 \\
& Organisational+patient oriented & 0.154 & $0.037-0.271$ & 0.017 \\
& Professional+organisational+patient oriented & -0.165 & $-0.332-0.002$ & 0.053 \\
\hline 3. & Single component strategy & -0.022 & & \\
& Multiple component strategy & 0.108 & $-0.068-0.284$ & 0.206 \\
\hline 4. & Study duration $\leq 12$ months & 0.056 & & \\
& Study duration 12 months or longer & -0.046 & $-0.361-0.270$ & 0.758 \\
\hline 5. & Physician participants only & 0.019 & & \\
& Physician participants combined & -0.011 & $-0.408-0.386$ & 0.947 \\
\hline
\end{tabular}

* Professional oriented implementation strategy was the reference category

Table 5. Meta-regression analysis: predictor variable effects on screening based on 11 outcomes from 10 studies

\begin{tabular}{lllll} 
Comparison & $\boldsymbol{\beta}$ & $\mathbf{9 5 \% - C I}$ & $\boldsymbol{p}$ \\
\hline 1. & Single implementation strategy & 0.158 & & \\
& Multiple implementation strategy & 0.675 & $0.021-1.330$ & 0.044 \\
\hline $2 . *$ & Organisational oriented & -0.129 & $-0.457-0.119$ & 0.358 \\
& Professional+organisational oriented & 0.034 & $-0.774-0.841$ & 0.919 \\
& Professional+pat oriented oriented & 1.231 & $0.562-1.900$ & 0.005 \\
& Professional+organisational+patient oriented & -0.114 & $-1.383-1.156$ & 0.827 \\
\hline 3. & Single component strategy & 0.192 & & 0.591 \\
\hline & Multiple component strategy & 0.121 & $-0.380-0.623$ & \\
\hline 4. & Study duration $\leq 12$ months & 0.349 & & 0.862 \\
\hline & Study duration 12 months or longer & -0.051 & $-0.725-0622$ & \\
\hline 5. & Physician participants only & 0.168 & & \\
& Physician participants combined & 0.767 & $0.24-1.295$ & 0.010 \\
\hline
\end{tabular}

* Professional oriented implementation strategy was the reference category

Table 6. Meta-regression analysis: predictor variable effects on brief interventions based on 10 outcomes from 8 studies

\begin{tabular}{lllll} 
Comparison & $\boldsymbol{\beta}$ & $\mathbf{9 5 \% - C I}$ & $\boldsymbol{p}$ \\
\hline 1. & Single implementation strategy & 0.169 & & \\
& Multiple implementation strategy & 1.018 & $0.165-1.871$ & 0.027 \\
\hline $2 . *$ & Organisational oriented & -0.077 & $-0.630-0.477$ & 0.720 \\
& Professional+patient oriented & 1.262 & $0.243-2.281$ & 0.026 \\
& Professional+organisational+patient oriented & -0.091 & $-1.868-1.686$ & 0.893 \\
\hline 3. & Single component strategy & 0.147 & & \\
& Multiple component strategy & 0.985 & $0.310-1.660$ & 0.012 \\
\hline 4. & Study duration $\leq 12$ months & -0.121 & & \\
& Study duration 12 months or longer & 1.003 & $0.023-1.983$ & 0.046
\end{tabular}




\begin{tabular}{lllll}
\hline 5. & Physician participants only & 0.189 & & \\
& Physician participants combined & -0.089 & $-0.882-0.703$ & 0.797 \\
\hline
\end{tabular}

* Professional oriented implementation strategy was the reference category 


\section{Figures}

\section{Figure 1}
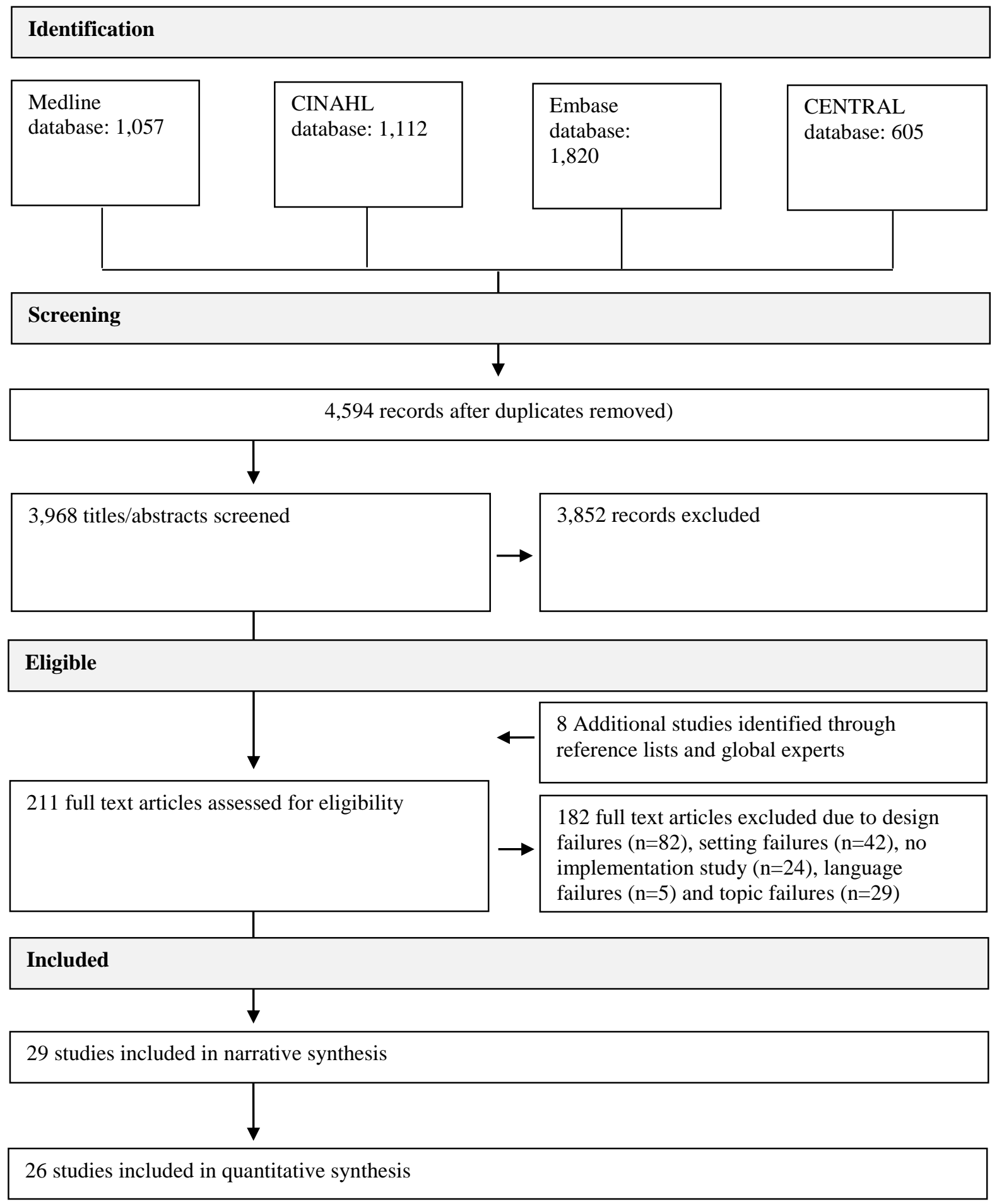


\section{Figure 2}

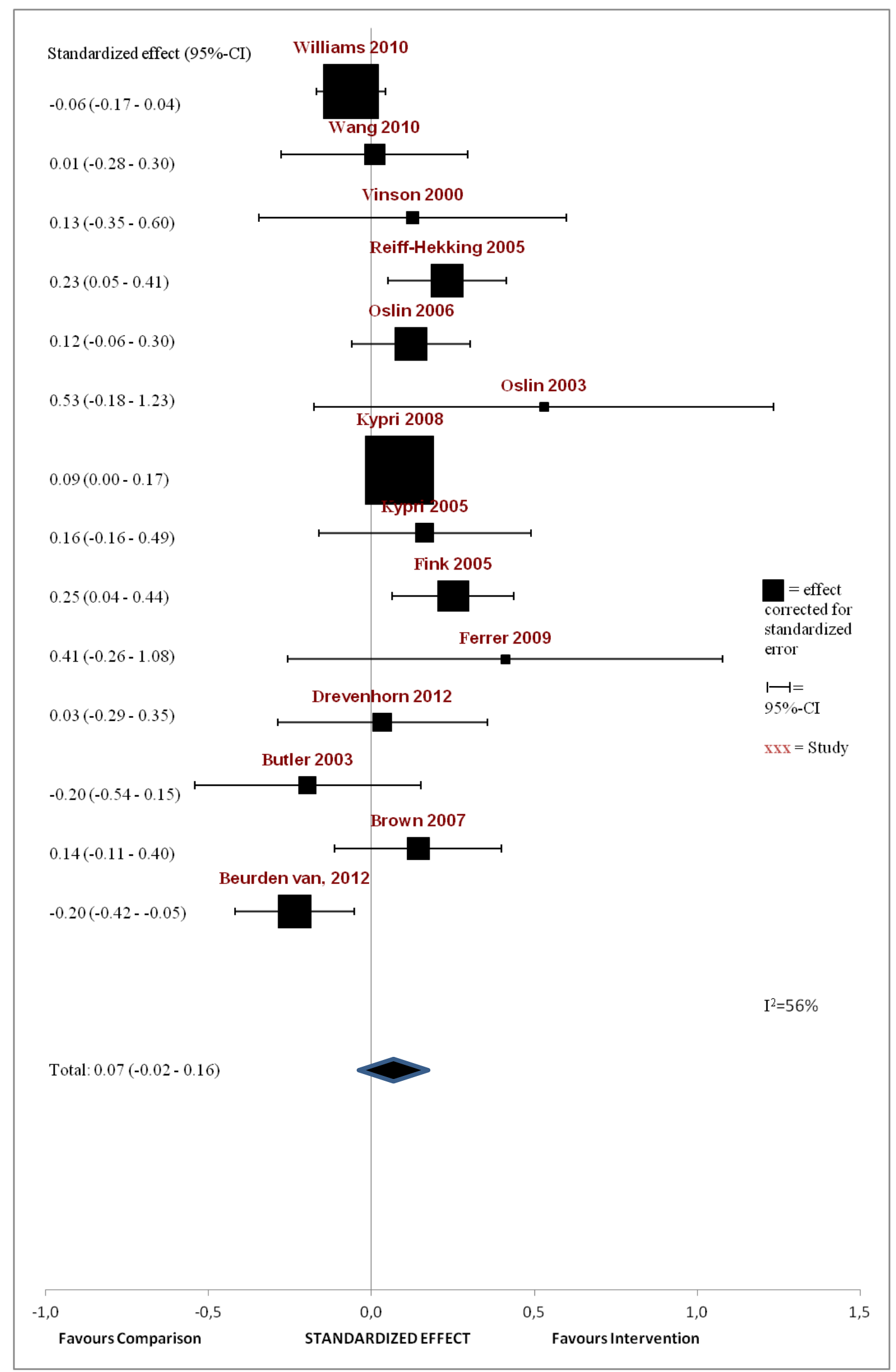


Figure 3

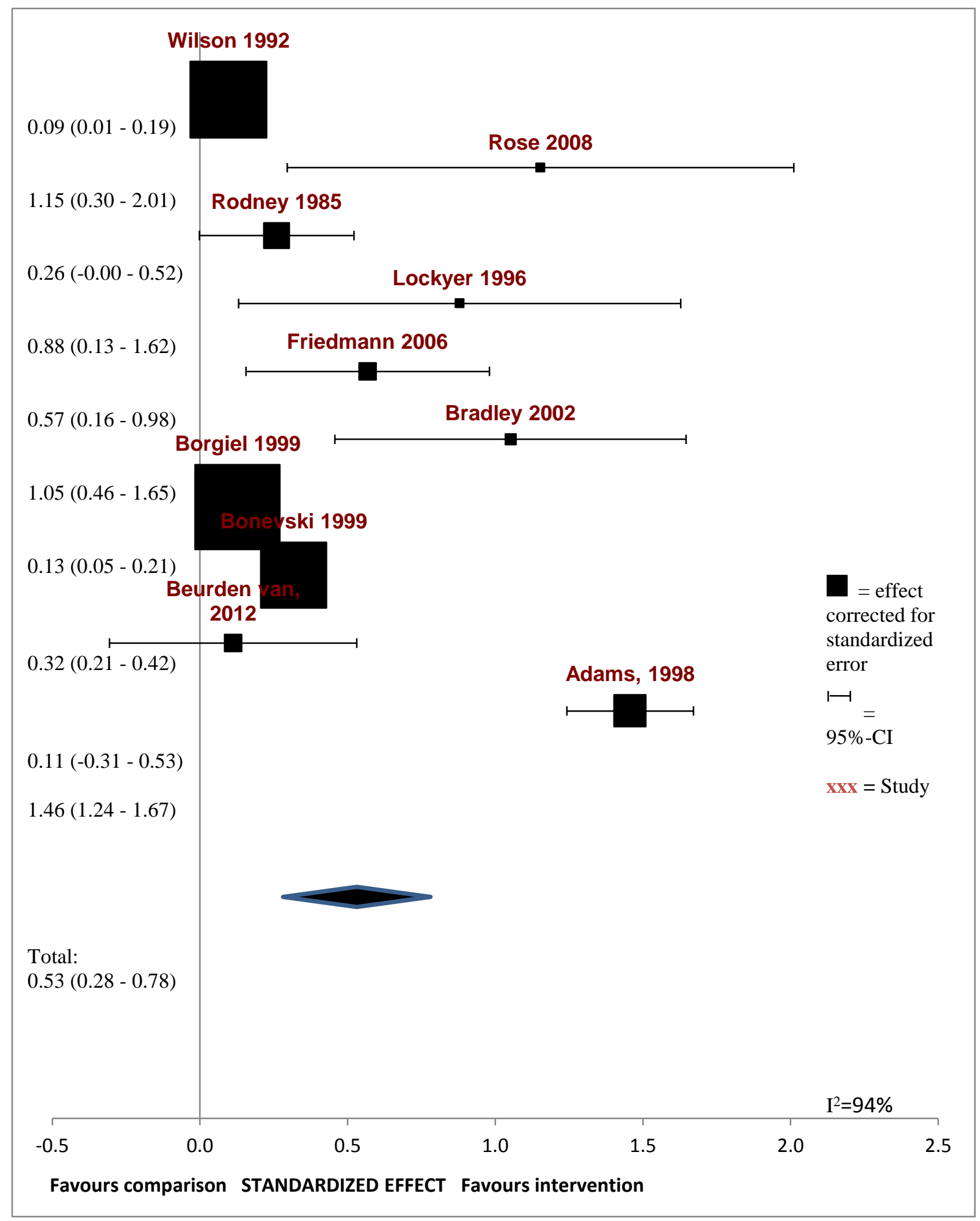




\section{Figure 4}

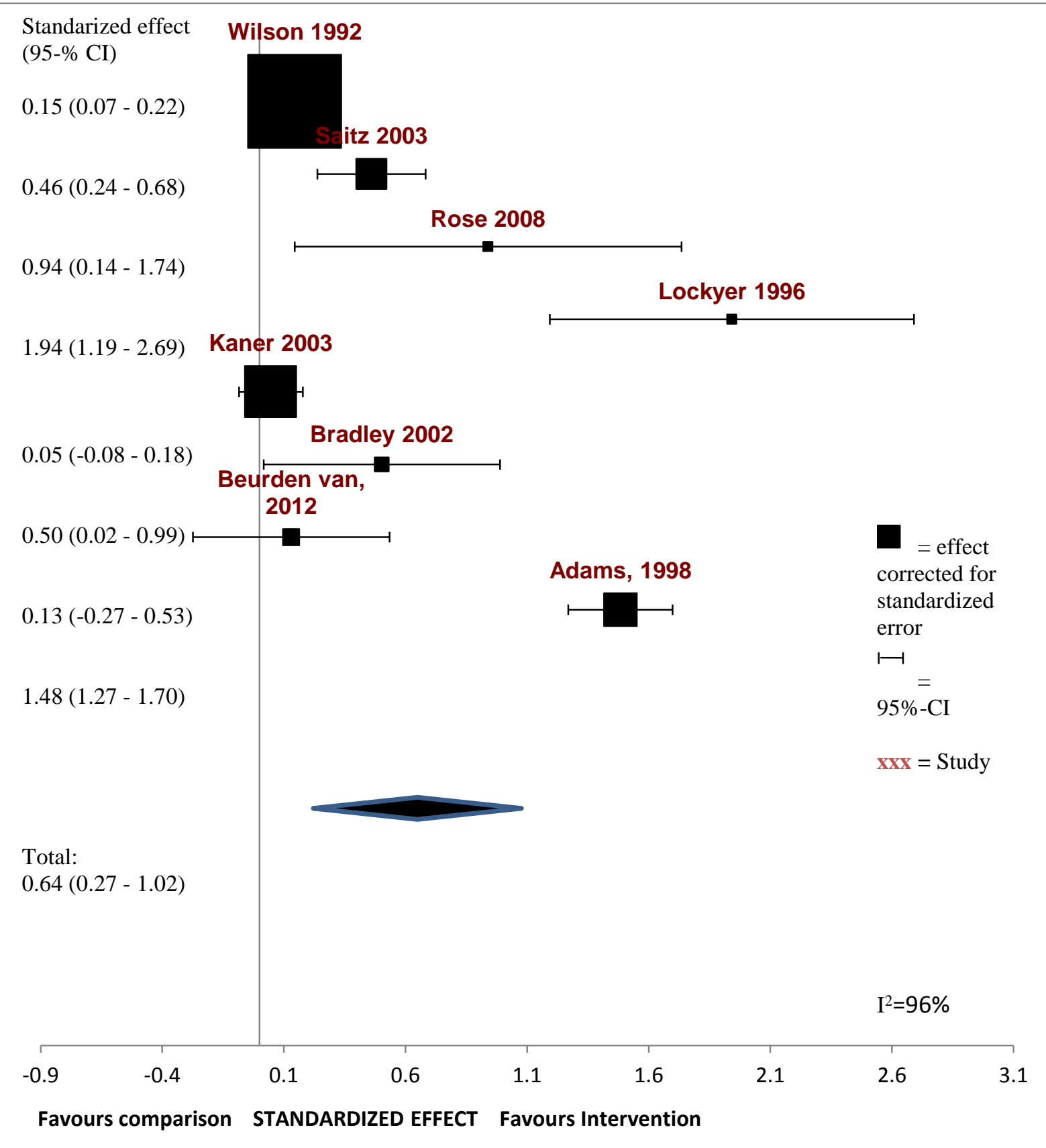

